\title{
Cleanup Verification Package for the 618-3 Burial Ground
}

\author{
Prepared for the U.S. Department of Energy \\ by Washington Closure Hanford
}




\section{EXECUTIVE SUMMARY}

This cleanup verification package documents completion of remedial action for the 618-3 Solid Waste Burial Ground, also referred to as Burial Ground Number 3 and the Dry Waste Burial Ground Number 3. This site is located in the 300-FF-2 Operable Unit in the 600 Area of the Hanford Site in southeastern Washington State. During its period of operation from 1954 to 1955 , the 618-3 site was used to dispose of uraniumcontaminated construction debris from the 311 Building and construction/demolition debris from remodeling of the $313,303-\mathrm{J}$, and $303-\mathrm{K}$ Buildings.

Site excavation and waste disposal of the 618-3 waste site are complete, and the exposed surfaces have been sampled and analyzed to verify attainment of the remedial action goals. Results of the sampling, laboratory analyses, and data evaluations for the 618-3 Solid Waste Burial Ground indicate that all remedial action objectives for direct exposure, protection of groundwater, and protection of the Columbia River have been met (see Table ES-1).

The site meets cleanup standards and has been reclassified as "interim closed out" in accordance with the Hanford Federal Facility Agreement and Consent Order (Ecology et al. 1989) and the Waste Site Reclassification Guideline TPA-MP-14 (RL-TPA-90-0001) (DOE-RL 1998). A copy of the waste site reclassification form is included as Attachment ES-1. 
Rev. 0

\section{Table ES-1. Summary of Cleanup Verification Results for the 618-3 Waste Site. (2 Pages)}

\begin{tabular}{|c|c|c|c|}
\hline Regulatory Requirement & Remedial Action Goals & Results & $\begin{array}{l}\text { Remedial } \\
\text { Action } \\
\text { Objectives } \\
\text { Attained? }\end{array}$ \\
\hline $\begin{array}{l}\text { Direct Exposure - } \\
\text { Radionuclides }\end{array}$ & $\begin{array}{l}\text { Attain } 15 \mathrm{mrem} / \mathrm{yr} \text { dose rate above } \\
\text { background over } 1,000 \text { years. Attain } \\
\text { the CERCLA risk range of } 10^{-4} \text { to } \\
10^{-6} \text {. }\end{array}$ & $\begin{array}{l}\text { Maximum concentrations of the only } \\
\text { radionuclide COC (uranium) are below } \\
\text { the } 15 \mathrm{mrem} / \mathrm{yr} \text { dose equivalence lookup } \\
\text { value for total uranium. }\end{array}$ & Yes \\
\hline $\begin{array}{l}\text { Direct Exposure - } \\
\text { Nonradionuclides }\end{array}$ & Attain individual COC RAGs. & $\begin{array}{l}\text { All individual COC concentrations are } \\
\text { below background; therefore, direct } \\
\text { exposure RAGs are met. }\end{array}$ & Yes \\
\hline \multirow[t]{4}{*}{$\begin{array}{l}\text { Nonradionuclide Risk } \\
\text { Requirements }\end{array}$} & $\begin{array}{l}\text { Attain hazard quotient of }<1 \text { for } \\
\text { noncarcinogens. }\end{array}$ & \multirow{2}{*}{$\begin{array}{l}\text { Hazard quotients were not calculated } \\
\text { because all nonradionuclide COCs were } \\
\text { detected below statistical background } \\
\text { levels. }\end{array}$} & \multirow{4}{*}{ NA } \\
\hline & $\begin{array}{l}\text { Attain cumulative hazard quotient of } \\
<1 \text { for noncarcinogens. }\end{array}$ & & \\
\hline & $\begin{array}{l}\text { Attain excess cancer risk of }<1 \times 10^{-5} \\
\text { for individual carcinogens. }\end{array}$ & \multirow{2}{*}{$\begin{array}{l}\text { Excess cancer risks were not calculated } \\
\text { because all nonradionuclide carcinogenic } \\
\text { coCs were detected below statistical } \\
\text { background levels. }\end{array}$} & \\
\hline & $\begin{array}{l}\text { Attain a total excess cancer risk of } \\
<1 \times 10^{-5} \text { for carcinogens. }\end{array}$ & & \\
\hline \multirow[t]{4}{*}{$\begin{array}{l}\text { Groundwater/River } \\
\text { Protection - Radionuclides }\end{array}$} & $\begin{array}{l}\text { Attain single COC groundwater and } \\
\text { river protection RAGs. }\end{array}$ & $\begin{array}{l}\text { All individual COC concentrations were } \\
\text { detected below the soil cleanup levels. }\end{array}$ & \multirow{4}{*}{ Yes } \\
\hline & $\begin{array}{l}\text { Attain National Primary Drinking } \\
\text { Water Standards: } 4 \text { mrem/yr } \\
\text { (beta/gamma) dose rate to target } \\
\text { receptors/organs. }\end{array}$ & $\begin{array}{l}\text { All individual COC concentrations were } \\
\text { detected below the soil cleanup levels } \\
\text { that are calculated based on drinking } \\
\text { water standards. }\end{array}$ & \\
\hline & $\begin{array}{l}\text { Meet drinking water standards for } \\
\text { nonuranium alpha emitters: the more } \\
\text { stringent of the } 15 \mathrm{pCi} / \mathrm{L} \mathrm{MCL} \\
\text { or } 1 / 25^{\text {th }} \text { of the derived concentration } \\
\text { guide per DOE Order } 5400.5 .^{b}\end{array}$ & $\begin{array}{l}\text { All individual COC concentrations were } \\
\text { detected below the soil cleanup levels. }\end{array}$ & \\
\hline & $\begin{array}{l}\text { Meet total uranium standard of } \\
21.2 \mathrm{pCi} / \mathrm{L} .\end{array}$ & $\begin{array}{l}\text { Uranium statistical values are below } \\
\text { background for this site. Uranium } \\
\text { detected in the discrete samples meets } \\
\text { the } 21.2 \mathrm{pCi} / \mathrm{L} \text { total uranium standard. }\end{array}$ & \\
\hline $\begin{array}{l}\text { Groundwater/River } \\
\text { Protection - } \\
\text { Nonradionuclides }\end{array}$ & $\begin{array}{l}\text { Attain individual nonradionuclide } \\
\text { groundwater and river cleanup } \\
\text { requirements. }\end{array}$ & $\begin{array}{l}\text { All individual COC concentrations were } \\
\text { detected below the soil cleanup levels; } \\
\text { therefore, groundwater and river } \\
\text { protection RAGS are met. }\end{array}$ & Yes \\
\hline
\end{tabular}


CVP-2006-00005

Rev. 0

\section{Table ES-1. Summary of Cleanup Verification Results for the 618-3 Waste Site. (2 Pages)}

\begin{tabular}{|l|l|l|l|}
\hline Regulatory Requirement & \multicolumn{1}{|c|}{ Remedial Action Goals } & Results & $\begin{array}{c}\text { Remedial } \\
\text { Action } \\
\text { Objectives } \\
\text { Attained? }\end{array}$ \\
\hline Supporting Information & $\begin{array}{l}618-3 \text { cleanup verification sample location design (Appendix } C \text { ). }{ }^{e} \\
618-3 \text { cleanup verification } 95 \% \mathrm{CL} \text { calculation (Appendix } \mathrm{C}) .^{\mathrm{e}}\end{array}$ \\
\hline
\end{tabular}

a "National Primary Drinking Water Regulations" (40 Code of Federal Regulations 141).

b Radiation Protection of the Public and the Environment (DOE Order 5400.5).

c Based on the isotopic distribution of uranium in the Hanford Site background, the $30 \mu \mathrm{g} / \mathrm{L} \mathrm{MCL}$ (65 Federal Register 76708) corresponds to $21.2 \mathrm{pCi} / \mathrm{L}$. Concentration-to-activity calculations are documented in Calculation of Total Uranium Activity Corresponding to a Maximum Contaminant Level for Total Uranium of 30 Micrograms per Liter in Groundwater, 0100X-CA-V0038 (BHI 2001).

d Uranium detected in the discrete samples meets the $21.2 \mathrm{pCi} / L$ per the Explanation of Significant Differences (ESD) for the $300-F F-2$ Operable Unit Record of Decision, 2004, U.S. Environmental Protection Agency, Region 10, Seattle, Washington.

e 618-3 Shallow Zone Sampling Plan, 0300X-CA-V0066, Rev. 0, Washington Closure Hanford, Richland, Washington.

f 618-3 Burial Ground Cleanup Verification 95\% UCL Calculations, 0600X-CA-V0057, Rev. 0, Washington Closure Hanford, Richland, Washington.

CERCLA = Comprehensive Environmental Response, Compensation, and Liability Act of 1980

$\mathrm{COC}=$ contaminant of concern

MCL = maximum contaminant level (drinking water standard)

NA = not applicable

RAG = remedial action goal

UCL = upper confidence limit 
CVP-2006-00005 Rev. 0

ES-4 
CVP-2006-00005

Rev. 0

\section{Attachment ES-1 \\ Waste Site Reclassification Form}

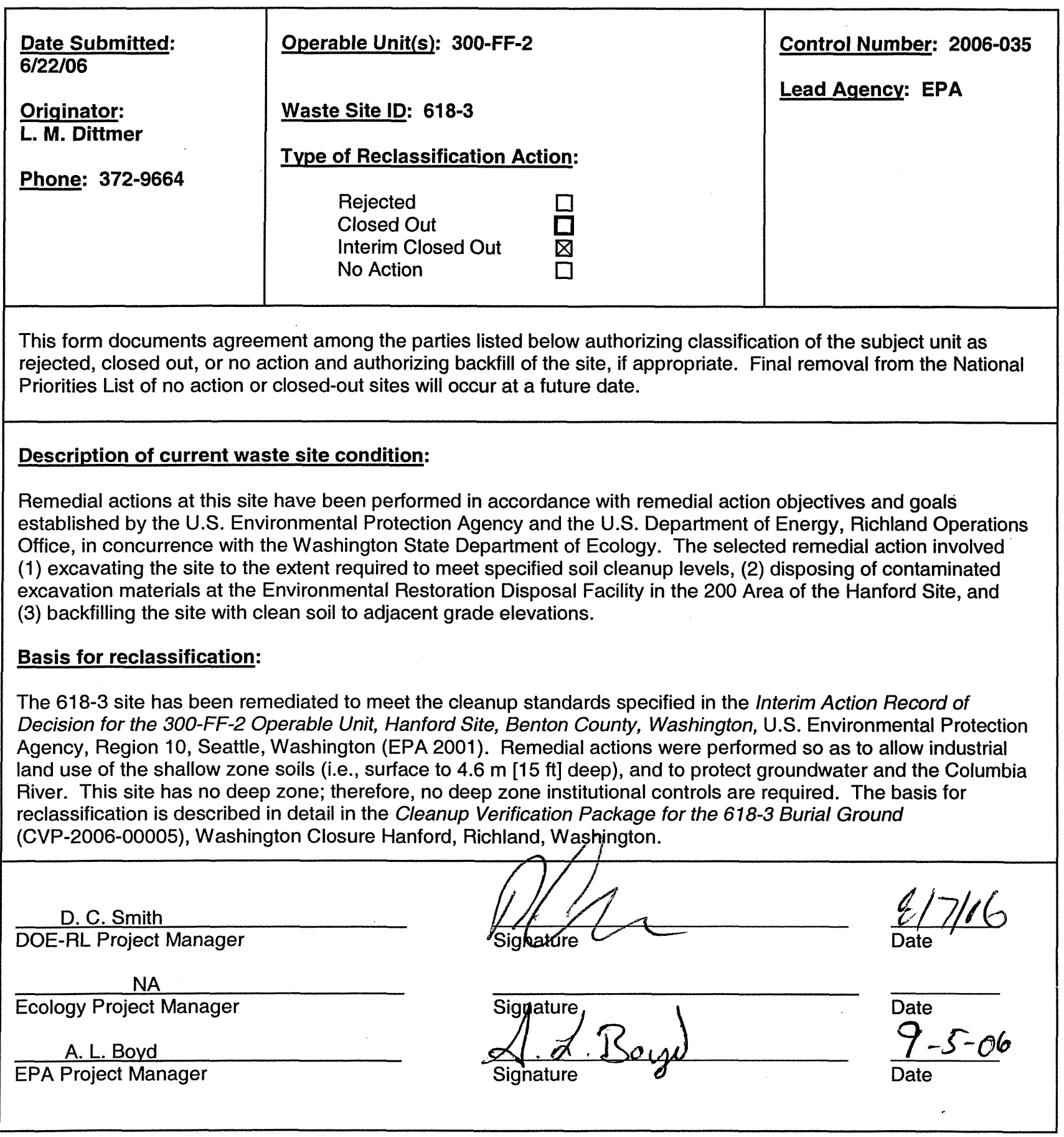


CVP-2006-00005

Rev. 0

ES-6 


\section{CONTENTS}

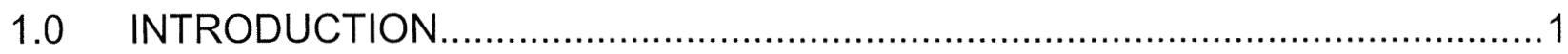

2.0 SITE DESCRIPTION AND SUPPORTING INFORMATION …..........................

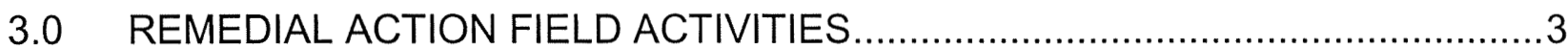

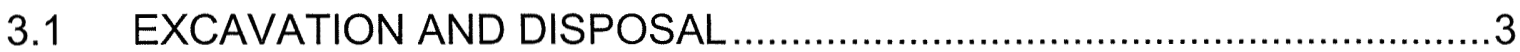

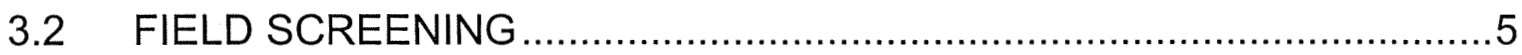

3.3 BIASED SAMPLING AND ANALYSIS ..........................................

3.4 CLEANUP VERIFICATION SAMPLING AND ANALYSIS ....................10

4.0 CLEANUP VERIFICATION DATA EVALUATION .........................................10

4.1 DATA QUALITY ASSESSMENT PROCESS ...................................10

4.2 CONTAMINANTS OF CONCERN 95\% UPPER CONFIDENCE LIMIT ...11

4.3 BIASED SAMPLE RESULTS ....................................................11

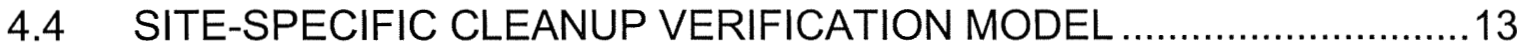

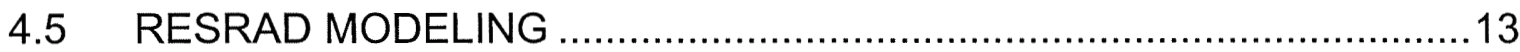

5.0 EVALUATION OF REMEDIAL ACTION GOAL ATTAINMENT …....................13

5.1 DIRECT EXPOSURE SOIL REMEDIAL ACTION GOALS ATTAINED ....13

5.1.1 Radionuclides ...................................................................13

5.1.2 Nonradionuclides.................................................................. 14

5.2 GROUNDWATER REMEDIAL ACTION GOALS ATTAINED .................14

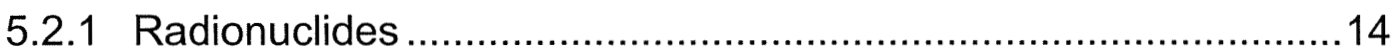

5.2.2 Nonradionuclides ................................................................ 14

5.3 COLUMBIA RIVER REMEDIAL ACTION GOALS ATTAINED ................14

5.3.1 Radionuclides ................................................................. 14

5.3.2 Nonradionuclides ................................................................ 15

5.4 WAC 173-340 THREE-PART TEST FOR NONRADIONUCLIDES ..........15

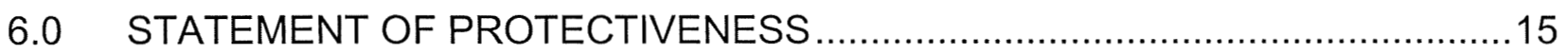

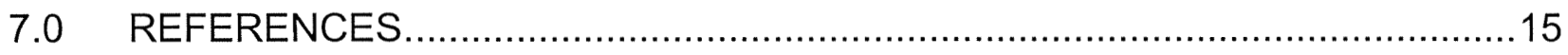




\section{APPENDICES}
A SUMMARY OF VERIFICATION SOIL SAMPLING AND ANALYTICAL

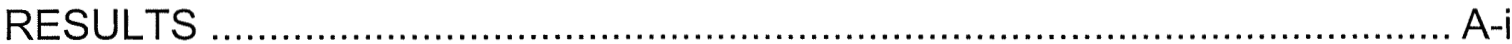

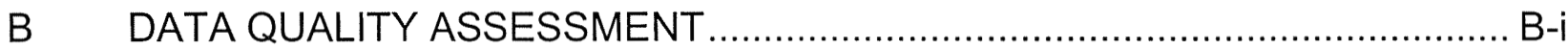
C CALCULATION BRIEF EXCERPTS …....................................................
C1 618-3 Burial Ground Cleanup Verification 95\% UCL Calculations

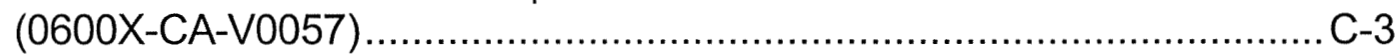
C2 618-3 Shallow Zone Sampling Plan (0300X-CA-V0066) ........................ -9

\section{FIGURES}

1. Hanford Site Map and Location of the 618-3 Waste Site. ..................................4

2. Pre-Remediation Topographic Map for the 618-3 Waste Site............................6

3. Post-Remediation Topographic Map Showing Biased Sampling Locations for the 618-3 Waste Site. 7

4. $\quad$ Radiological Mapping (Beta) Survey Results for the 618-3 Site..........................

5. Radiological Mapping (Gamma) Survey Results for the 618-3 Site. ....................

\section{TABLES}

1. Summary of Remedial Action Goals - Industrial Land Use..............................1

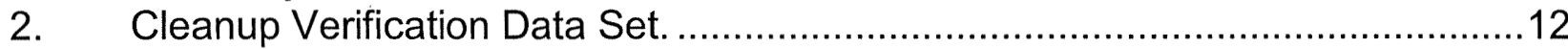

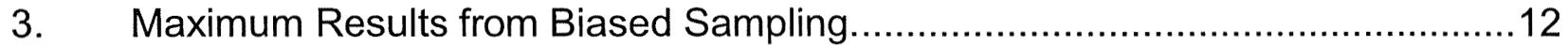




\section{ACRONYMS AND ABBREVIATIONS}

$\begin{array}{ll}\text { COC } & \text { contaminant of concern } \\ \text { CVP } & \text { cleanup verification package } \\ \text { DQA } & \text { data quality assessment } \\ \text { EPA } & \text { U.S. Environmental Protection Agency } \\ \text { ERDF } & \text { Environmental Restoration Disposal Facility } \\ \text { ESD } & \text { Explanation of Significant Differences } \\ \text { RAG } & \text { remedial action goal } \\ \text { RAO } & \text { remedial action objective } \\ \text { RDR/RAWP } & \text { remedial design report/remedial action work plan } \\ \text { RESRAD } & \text { RESidual RADioactivity (dose assessment model) } \\ \text { ROD } & \text { record of decision } \\ \text { SAP } & \text { sampling and analysis plan } \\ \text { UCL } & \text { upper confidence limit } \\ \text { WAC } & \text { Washington Administrative Code }\end{array}$


CVP-2006-00005

Rev. 0 


\subsection{INTRODUCTION}

This cleanup verification package (CVP) documents that the 618-3 waste site was remediated in accordance with the Interim Action Record of Decision for the 300-FF-2 Operable Unit, Hanford Site, Benton County, Washington (ROD) (EPA 2001), as modified by the Explanation of Significant Differences for the 300-FF-2 Operable Unit Interim Record of Decision (ESD) (EPA 2004). Remedial action objectives (RAOs) and remedial action goals (RAGs) for this site are documented in the ROD (EPA 2001) and the Remedial Design Report/Remedial Action Work Plan for the 300 Area (RDR/RAWP) (DOE-RL 2004b). The ROD provides the U.S. Department of Energy, Richland Operations Office, the authority, guidance, and objectives to conduct this remedial action.

The remedy specified in the ROD (EPA 2001) and conducted for the 618-3 waste site included (1) excavating the site to the extent required to meet specified soil cleanup levels, (2) disposing of contaminated excavation materials at the Environmental Restoration Disposal Facility (ERDF) in the 200 Area of the Hanford Site, and (3) backfilling the site with clean soil to average adjacent grade elevation. Excavation was driven by RAOs for direct exposure, protection of groundwater, and protection of the Columbia River. For the respective points of compliance, RAGs, summarized in Table 1, were established for the contaminants of concern (COCs) in the RDR/RAWP (DOE-RL 2004b) to support industrial land use. Preliminary waste site contaminants of potential concern were identified in the 300 Area Remedial Action Sampling and Analysis Plan (SAP) (DOE-RL 2004a). Following excavation of the site, final COCs were identified in the Closeout Plan for the 618-3 Burial Ground (WCH 2006a) and are listed in Table 1.

Table 1. Summary of Remedial Action Goals - Industrial Land Use. (2 Pages)

\begin{tabular}{|l|c|c|c|}
\hline Contaminants of Concern & $\begin{array}{c}\text { Industrial Soil } \\
\text { Cleanup Level for } \\
\text { Direct Exposure } \\
\text { (pCi/g) }\end{array}$ & $\begin{array}{c}\text { Industrial Soil } \\
\text { Cleanup Level for } \\
\text { Groundwater }^{\text {Protection }}{ }^{\mathrm{b}} \\
\text { (pCi/g) }\end{array}$ & $\begin{array}{c}\text { Industrial Soil Cleanup } \\
\text { Level for River }^{\text {Protection }} \\
\text { (pCi/g) }\end{array}$ \\
\hline \multicolumn{4}{|c|}{ Radionuclides } \\
\hline Uranium-233/234 & $169^{\mathrm{d}}$ & $129^{\mathrm{e}}$ & $129^{\mathrm{e}}$ \\
\hline Uranium-235 & $17^{\mathrm{d}}$ & $13^{\mathrm{e}}$ & $13^{\mathrm{e}}$ \\
\hline Uranium-238 & $164^{\mathrm{d}}$ & $125^{\mathrm{e}}$ & $125^{\mathrm{e}}$ \\
\hline Uranium (Total) & $350^{\dagger}$ & $267^{\mathrm{g}}$ & $267^{\mathrm{g}}$ \\
\hline
\end{tabular}


Table 1. Summary of Remedial Action Goals - Industrial Land Use. (2 Pages)

\begin{tabular}{|l|c|c|c|}
\hline \multicolumn{1}{|c|}{ Contaminants of Concern } & $\begin{array}{c}\text { Industrial } \\
\text { Soil Cleanup } \\
\text { Level for Direct } \\
\text { Contact } \\
\text { (mg/kg) }\end{array}$ & $\begin{array}{c}\text { Industrial Soil } \\
\text { Cleanup Level for } \\
\text { Groundwater } \\
\text { Protection } \\
\text { (mg/kg) }\end{array}$ & $\begin{array}{c}\text { Industrial Soil Cleanup } \\
\text { Level for River } \\
\text { Protection }^{\mathbf{j}} \\
\text { (mg/kg) }\end{array}$ \\
\hline Arsenic & \multicolumn{3}{|c|}{ Nonradionuclides } \\
\hline Barium & $58^{\mathrm{k}}$ & $\mathrm{NA}^{\prime}$ & $\mathrm{NA}^{\prime}$ \\
\hline Cadmium & $4,900^{\mathrm{k}}$ & $\mathrm{NA}^{\prime}$ & $\mathrm{NA}^{\prime}$ \\
\hline Chromium & $139^{\mathrm{k}}$ & $\mathrm{NA}^{\prime}$ & $\mathrm{NA}^{\prime}$ \\
\hline Lead & $>1,000,000^{\mathrm{m}}$ & $\mathrm{NA}^{\prime}$ & $\mathrm{NA}^{\prime}$ \\
\hline Selenium & $1,000^{\mathrm{n}}$ & $\mathrm{NA}^{\prime}$ & $\mathrm{NA}^{\prime}$ \\
\hline Silver & $17,500^{\circ}$ & $\mathrm{NA}^{\prime}$ & $\mathrm{NA}^{\prime}$ \\
\hline Uranium & $17,500^{\circ}$ & $\mathrm{NA}^{\prime}$ & $385^{\mathrm{p}}$ \\
\hline
\end{tabular}

${ }^{a}$ Direct exposure values represent soil activities for individual radionuclides that would meet the remedial action objective for cumulative risk (i.e., $10^{-4}$ to $10^{-6}$ risk under an industrial land-use scenario) from exposure to contaminated waste/soil. Values will be lower for multiple radionuclides to achieve the same risk endpoint. Listed values are calculated by RESRAD and apply to the top $4.6 \mathrm{~m}$ (15 ft) (DOE-RL 2004b).

b Groundwater protection values represent soil concentrations that will be protective of groundwater. Listed values are calculated by RESRAD, based on the applicable groundwater cleanup standard (DOE-RL 2004b).

c River protection values represent soil concentrations that will not cause applicable river cleanup standards to be exceeded as contaminants migrate through the soil column to groundwater, and from groundwater to the river. Listed values are calculated by RESRAD, based on the applicable river cleanup standard (DOE-RL 2004b).

d Values determined using uranium equilibrium isotopic ratios and the industrial scenario selected soil cleanup level for direct exposure for total uranium ( $350 \mathrm{pCi} / \mathrm{g}$ ) as provided in the Remedial Design Report/Remedial Action Work Plan for the 300 Area (300 Area RDR/RAWP) (DOE-RL 2004b).

e Values determined using uranium equilibrium isotopic ratios and the industrial scenario selected soil cleanup level for groundwater/river protection for total uranium (267 pCi/g) as provided in the 300 Area RDR/RAWP (DOE-RL 2004b).

$f$ Listed value is equal to a $15 \mathrm{mrem} / \mathrm{yr}$ dose, based on the isotopic distribution of uranium-234, uranium-235, and uranium-238 in the 300 Area.

g Value calculated using RESRAD, based on the generic site model, with a length parallel to groundwater of $100 \mathrm{~m}(328 \mathrm{ft})$ and distribution coefficient values of $8.9 \mathrm{~mL} / \mathrm{g}$ for the contaminated zone and $0 \mathrm{~mL} / \mathrm{g}$ for the saturated zone (with no unsaturated, uncontaminated zone) (DOE-RL 2004b)

${ }^{\mathrm{h}}$ Direct contact values represent soil concentrations that are protective of human receptors from direct contact with contaminated waste/soil. Listed WAC 173-340-745(4), Method C cleanup standards for industrial soil apply to the top $4.6 \mathrm{~m}$ (15 ft) (WAC 173-340-745[6]).

i Groundwater protection values represent soil concentrations that will be protective of groundwater. Values are equal to 100 times the groundwater cleanup standard (WAC 173-340-745(4)(a)(ii)(A)), unless otherwise noted.

j River protection values represent soil concentrations that will not cause applicable river cleanup levels to be exceeded as contaminants migrate through the soil column to groundwater, and from groundwater to the river. Listed values are equal to 100 times the applicable river cleanup standard multiplied by a dilution attenuation fact of 2 , unless otherwise noted.

${ }^{k}$ Cleanup limit based on the inhalation exposure pathway per WAC 173-340-750(4)(b)(ii)(A) or (B), (1996).

1 The RESRAD model predicts that the constituent will not reach groundwater within 1,000 years based on a generic site profile (4.0-m [13.1-ft] contaminated zone and 5.6-m [18.4-ft] uncontaminated zone) (DOE-RL 2004b).

${ }^{m}$ Direct contact soil cleanup levels calculated using WAC 173-340-745(4) can result in values greater than pure material (e.g., $>1$ million parts per billion) (DOE-RL 2004b).

$n$ The $1,000 \mathrm{mg} / \mathrm{kg}$ lead value reflects the Method A soil cleanup level from WAC 173-340-745 (1996).

- Noncarcinogenic cleanup level calculated from WAC 173-340-745(4), Method C (1996).

$\mathrm{p}$ Based on the calculated isotopic distribution of uranium in the 300 Area and cleanup levels of $350 \mathrm{pCi} / \mathrm{g}$ and $267 \mathrm{pCi} / \mathrm{g}$ for total uranium, the corresponding uranium concentration is $505 \mathrm{mg} / \mathrm{kg}$ and $385 \mathrm{mg} / \mathrm{kg}$, respectively (BHI 2002) for 300-FF-2 Operable Unit sites.

NA $\quad$ not applicable

RESRAD = RESidual RADioactivity (dose assessment model)

WAC $\quad$ Washington Administrative Code 
Soil cleanup levels were established in the ROD based on a limited ecological risk assessment. Although not required by the ROD, a comparison against ecological risk screening levels has been made for the site COCs. Screening values were not exceeded for the COCs for this site, with the exception of selenium and the total uranium detected in the biased sample results. Exceedance of screening values does not necessarily indicate the existence of risk to ecological receptors. It is believed that the presence of selenium at this site does not pose a risk to ecological receptors because concentrations of selenium are within the range of natural site background (DOE-RL 1996). For the exceedance of uranium, the biased samples were taken from

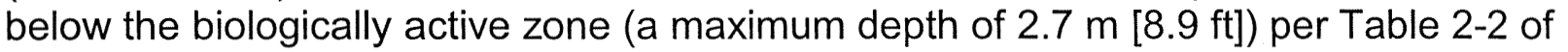
the 100 Area Burial Grounds Focused Feasibility Study (DOE-RL 2000). As such, these concentrations of uranium will not be accessible to ecological receptors. A baseline risk assessment for the river corridor portion of the Hanford Site began in 2004, which includes a more complete quantitative ecological risk assessment. That baseline risk assessment will be used as part of the final ROD for these sites.

\subsection{SITE DESCRIPTION AND SUPPORTING INFORMATION}

The 618-3 Solid Waste Burial Ground is part of the 300-FF-2 Operable Unit in the 600 Area. The waste site, which is also referred to as Burial Ground Number 3 and Dry Waste Burial Ground Number 3, consists of one north-south-trending trench

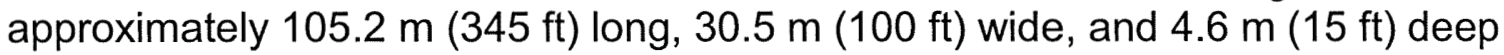
(WCH 2006a). The burial ground was operated from 1954 to 1955 for the disposal of uranium-contaminated construction debris from the 311 Building and construction/demolition debris from remodeling of the 313, 303-J, and 303-K Buildings. The burial ground is located north of the 300 Area exclusion fences, immediately north of the 333 Building and adjacent to the 618-2 Burial Ground (Figure 1).

\subsection{REMEDIAL ACTION FIELD ACTIVITIES}

\subsection{EXCAVATION AND DISPOSAL}

Remedial action activities at the 618-3 waste site were conducted from September 9, 2004, to October 28, 2004 (WCH 2006a, 2006b). Remediation activities were conducted in accordance with the RDR/RAWP (DOE-RL 2004b). Remediation involved excavation and removal of buried waste and contaminated soil to the extent required to satisfy the RAOs and corresponding RAGs. In-process radiological field screening was conducted during the site remedial actions. Field screening was used to guide the excavation to quickly assess the presence and level of contamination. The radiological survey results were consistent with the presence of uranium, at relatively low concentrations. There was no indication of additional radioactive contamination beyond the low levels of uranium (WCH 2006a). 
Figure 1. Hanford Site Map and Location of the 618-3 Waste Site.

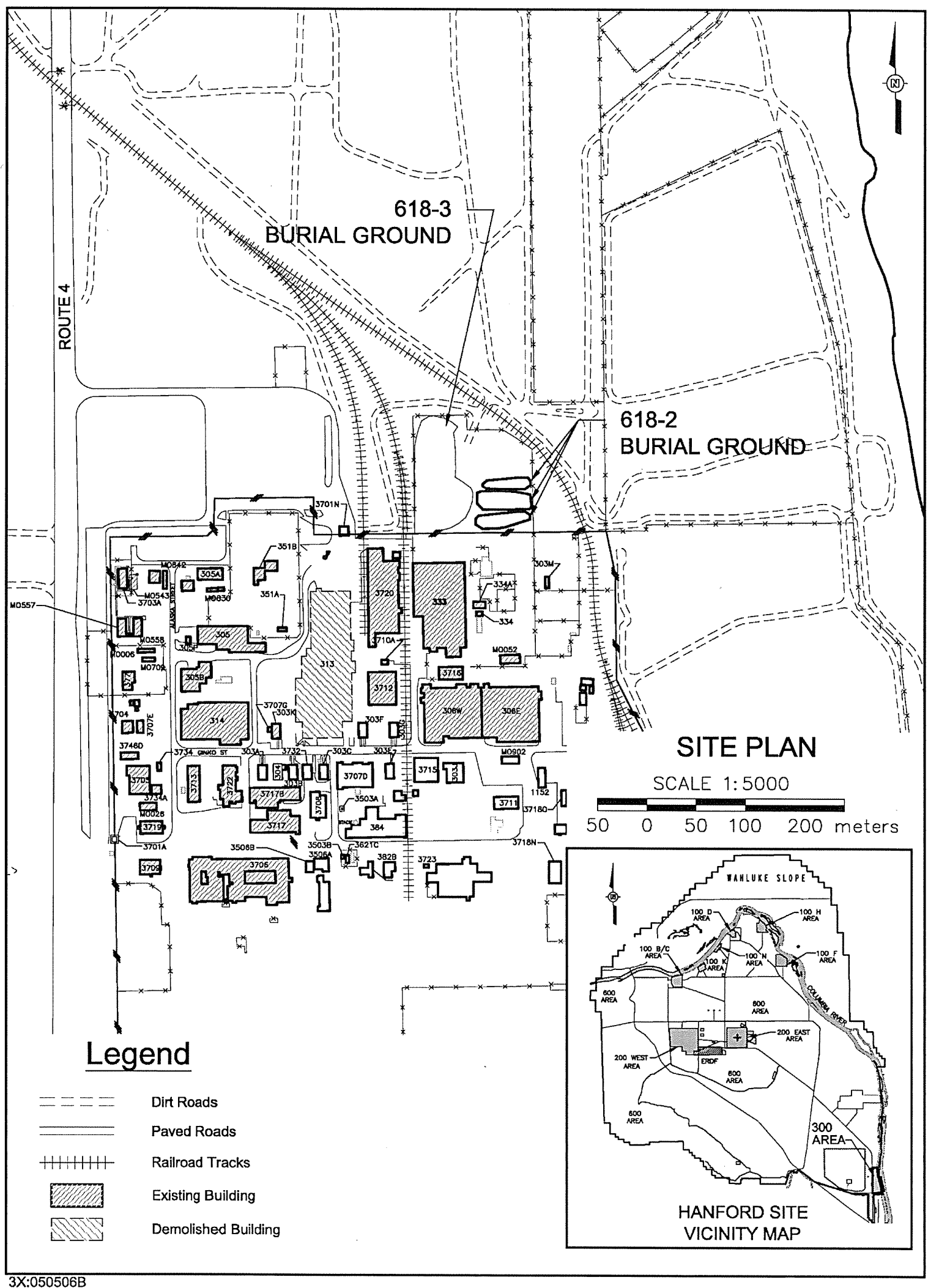


The buried waste consisted primarily of a wide variety of construction-type debris. Excavation activities found no indication of bulk liquid waste disposal at this waste site. Land disposal restriction materials, primarily consisting of lead solids, were identified and separated from the bulk soil and debris during excavation and sorting operations (WCH 2006a). Sorting and sampling of the excavated soil and debris was performed in a designated staging pile area. This staging pile area supported the 618-2, 618-3, and 618-8 Burial Ground excavations and will be closed out with the 618-2 waste site. No overburden piles were created during the waste site excavation. All excavated materials were disposed at ERDF. Approximately 30,878 metric tons $(34,037$ U.S. tons) of material from the site was removed and disposed at ERDF (WCH 2006a). Pre- and post-remediation topographic civil survey results for the 618-3 waste site are depicted in Figures 2 and 3, respectively.

\subsection{FIELD SCREENING}

Radiological surveys were performed in November 2004, after excavation operations were substantially complete at the 618-3 waste site to provide an initial assessment of attainment of radiological cleanup levels (WCH 2006a). The survey results identified several "hot spot" areas of residual radiological contamination requiring additional site excavation. Following completion of these remedial activities, new surveys were conducted in November and December 2005, using a plastic scintillation detector (SHP-380AB) for beta radiological activity and a sodium iodide detector for gamma radiation. The plastic scintillation detector was used in addition to the sodium iodide detector because it responds principally to the beta radiation emitted by the uranium-238 progeny and is therefore a good indicator of residual uranium contamination. The results of the beta and the gamma surveys are provided in Figures 4 and 5, respectively. Results of the beta radiological survey indicated that suspect hot spots may be present. Soil from these suspect hot spots was sampled on November 30, 2005, as described in Section 3.3 of this CVP.

\subsection{BIASED SAMPLING AND ANALYSIS}

Biased samples are typically collected at locations where significant quantities of specific waste streams were unearthed from a common area to help verify the absence of hot spots in the residual soil. At the 618-3 waste site, contamination and debris were spread throughout the excavation rather than in any discrete areas. No containerized liquid was found, and no evidence of historical liquid disposal was identified during the excavation. As such, biased samples were collected only from those areas identified during the post-excavation radiological surveys as having suspected residual contamination. The survey methodology was based on an assumption of uranium as the primary radiological contaminant. Results of the survey are depicted on a map based on various ranges of detected uranium activity (Figure 4), with $<50 \mathrm{pCi} / \mathrm{g}$ being the lowest reported range based on instrument sensitivity. On November 30, 2005, three biased soil samples were collected from suspect hot spots on the excavation floor (Figures 3 and 4), where the survey results indicated uranium activities $>200 \mathrm{pCi} / \mathrm{g}$. 
Figure 2. Pre-Remediation Topographic Map for the 618-3 Waste Site.

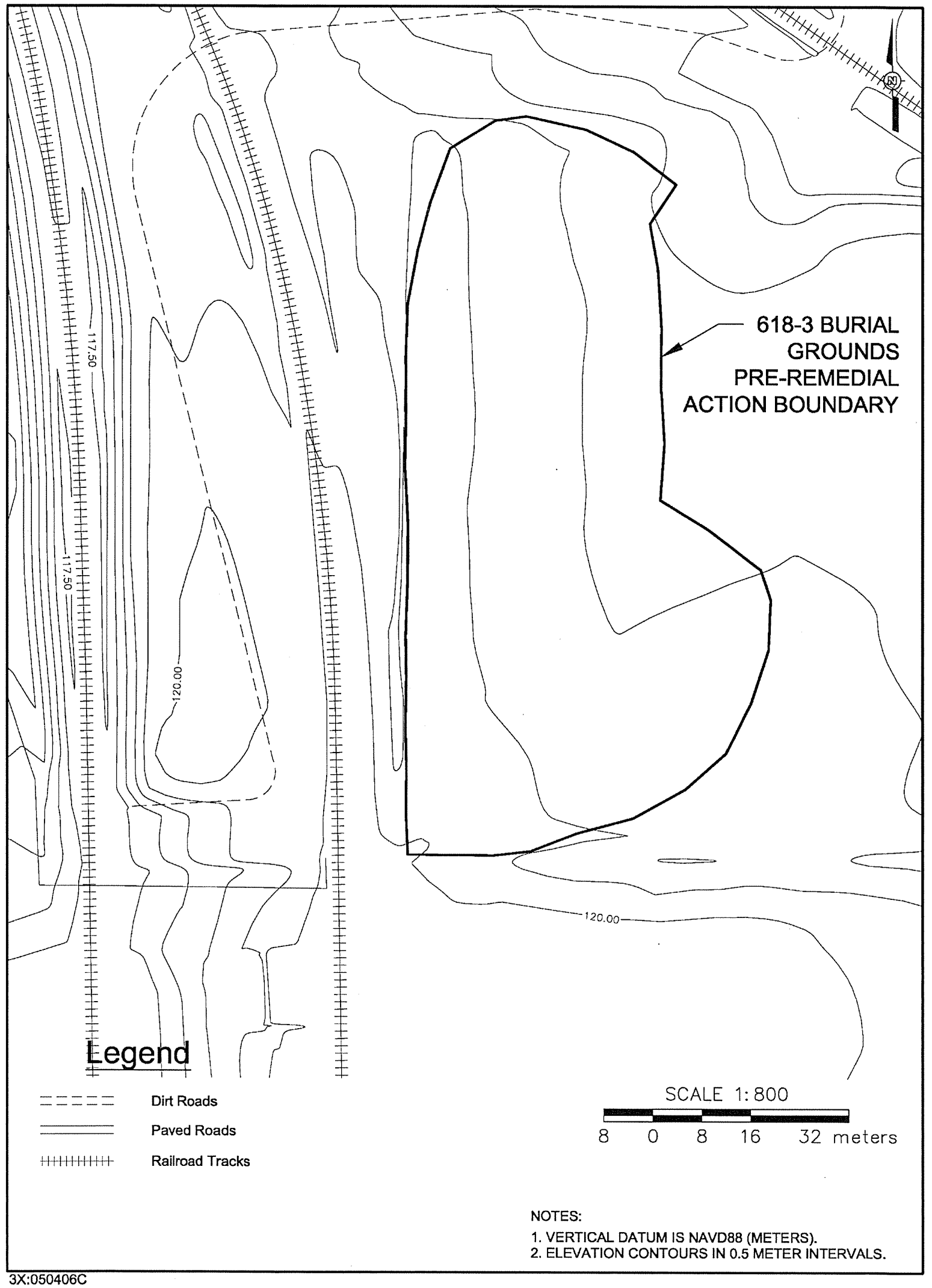


CVP-2006-00005

Rev. 0

Figure 3. Post-Remediation Topographic Map Showing Biased Sampling Locations for the 618-3 Waste Site.

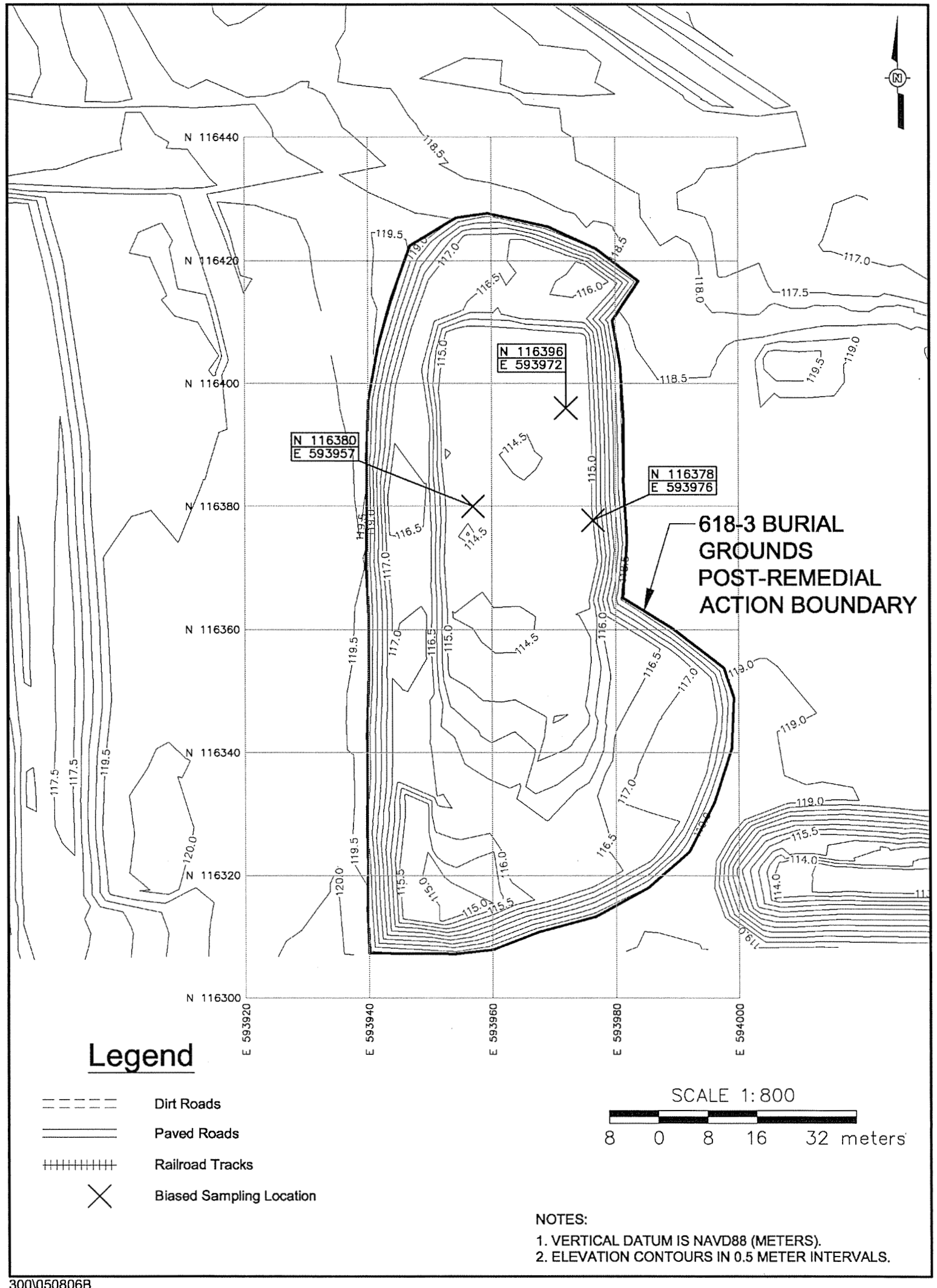




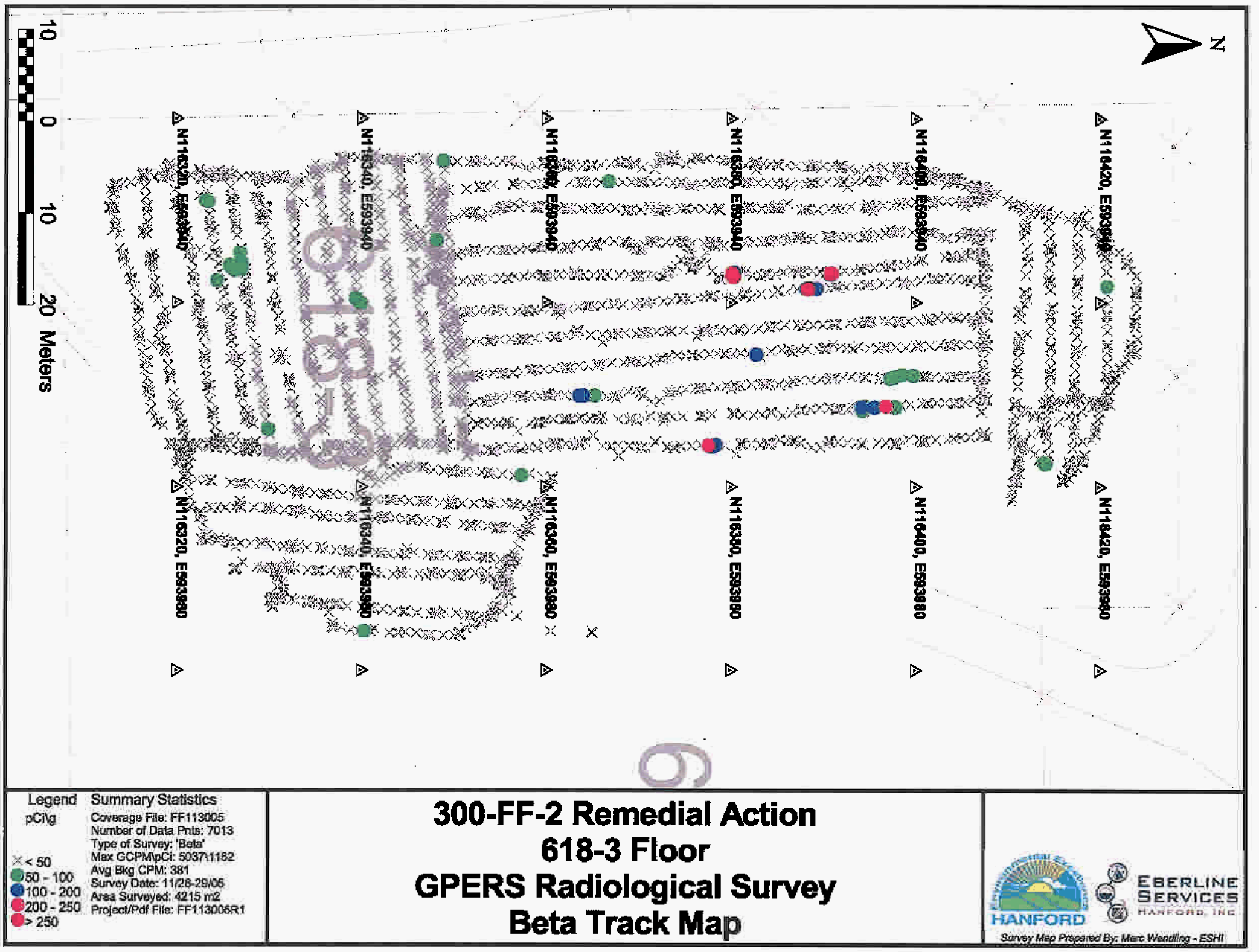

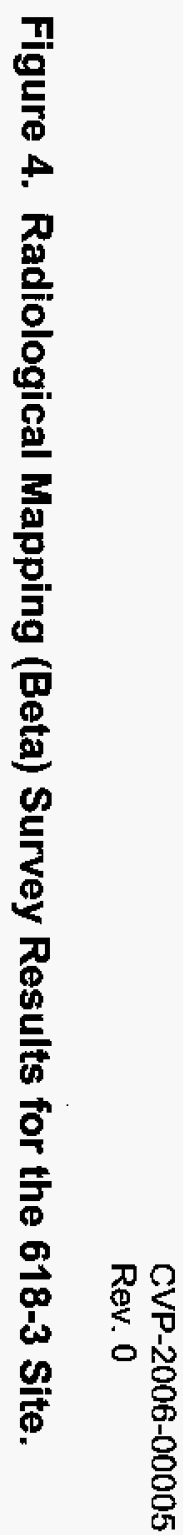




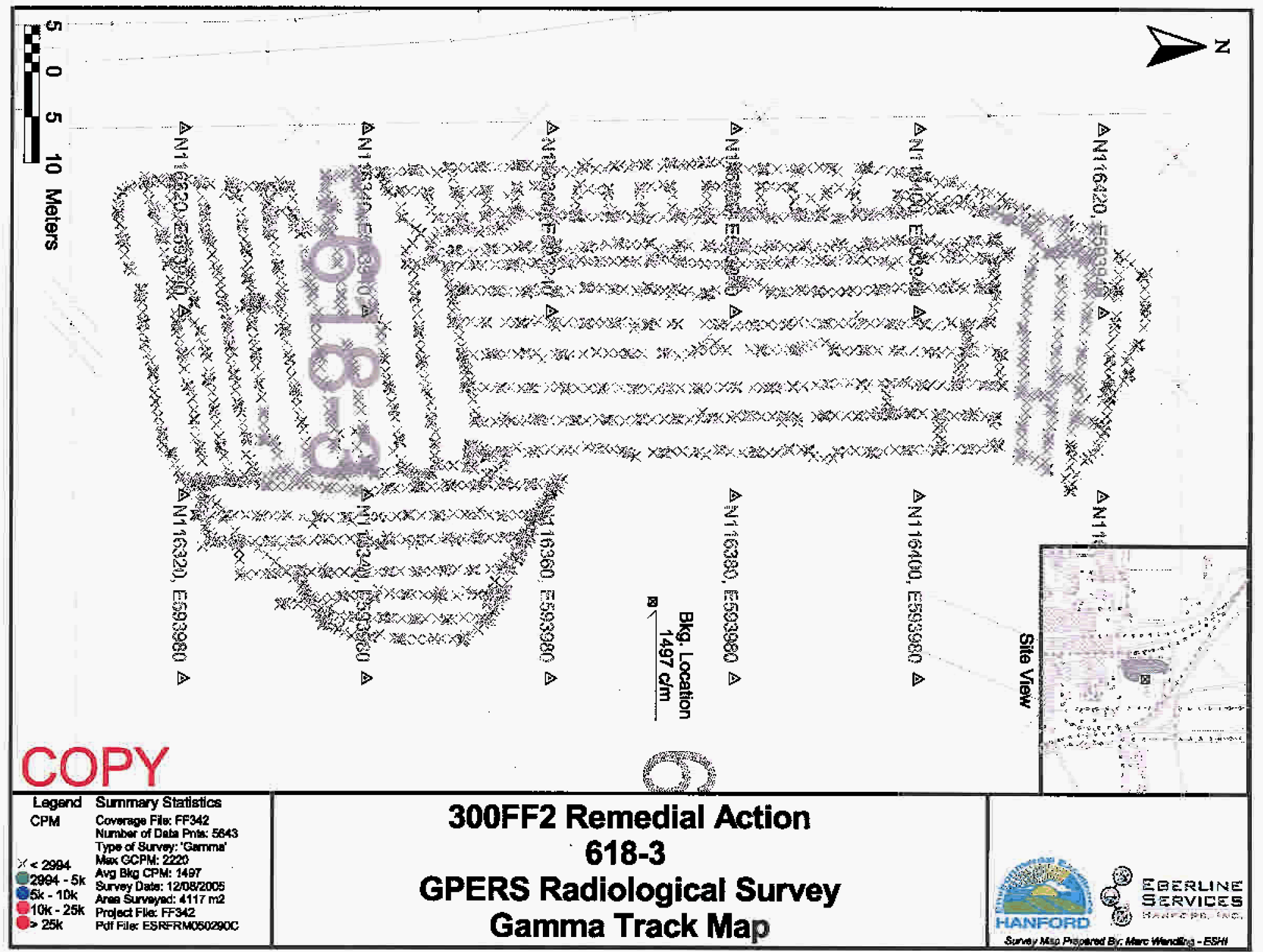

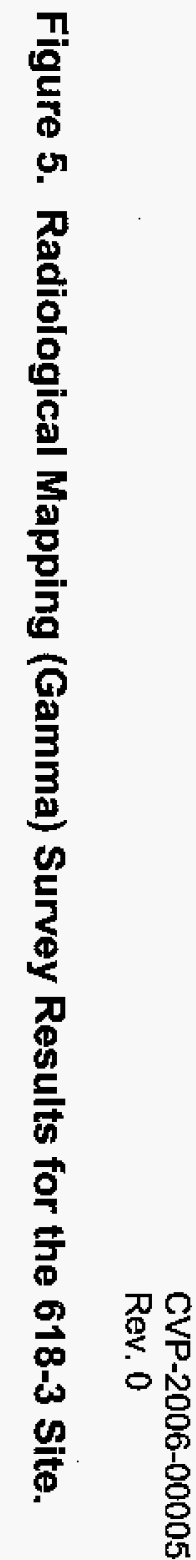


These areas were removed during sampling. These samples were analyzed for isotopic uranium (WCH 2006a, 2006b). The results of the biased sampling are discussed further in Section 4.3 of this CVP.

\subsection{CLEANUP VERIFICATION SAMPLING AND ANALYSIS}

Final cleanup verification sampling was conducted on January 31,2006 , to confirm acceptability of residual contaminant concentrations in the soil at the 618-3 waste site (WCH 2006a, 2006b). Based on the overall footprint of the area and depth of excavation, the 618-3 site was classified as one shallow zone decision unit. The final verification samples were submitted to offsite laboratories for analysis using approved U.S. Environmental Protection Agency (EPA) analytical methods as required per the SAP (DOE-RL 2004a).

Four verification samples, a duplicate, and an equipment blank were collected at the 618-3 Burial Ground. In accordance with the SAP (DOE-RL 2004a), each verification sample was collected as a composite sample formed by combining soil collected at four random locations within the remediation footprint. The sample design methodology and sample location figures are presented in the sample design calculation brief in Appendix C.

\subsection{CLEANUP VERIFICATION DATA EVALUATION}

This section presents the evaluation and modeling of the 618-3 cleanup verification data for comparison with the data quality criteria and RAGs.

\subsection{DATA QUALITY ASSESSMENT PROCESS}

A data quality assessment (DQA) is performed to compare the verification sampling approach and resulting analytical data with the sampling and data quality requirements specified by the project objectives and performance specifications.

The DQA for the 618-3 waste site determined that the data are of the right type, quality, and quantity to support site verification decisions within specified error tolerances. All analytical data were found to be acceptable for decision-making purposes. The evaluation also verified that the sample design was sufficient to support clean site verification. The cleanup verification sample analytical data are stored in the Environmental Restoration database prior to archiving in the Hanford Environmental Information System and are summarized in Appendix A. The detailed DQA is presented in Appendix B. 


\subsection{CONTAMINANTS OF CONCERN 95\% UPPER CONFIDENCE LIMIT}

The primary statistical calculation to support cleanup verification is the $95 \%$ upper confidence limit (UCL) on the arithmetic mean of the data. The $95 \%$ UCL values for each COC are computed for the decision unit. Prior to calculating the $95 \%$ UCL, the individual sample results are reviewed and, as appropriate, adjusted per the SAP (DOE-RL 2004a). This process is summarized below.

For radionuclides, the laboratory-reported value is used in the calculation of the $95 \%$ UCL. In cases where the laboratory does not report a value for data qualified with a "U" (i.e., less than the detection limit), one-half of the minimum detectable activity is used in the calculation of the $95 \% \mathrm{UCL}$. For nonradionuclides, a value equal to one-half the practical quantitation limit is used for data flagged with a " $U$ " (i.e., less than the detection limit) in the calculation of the $95 \% \mathrm{UCL}$, as required by Washington Administrative Code (WAC) 173-340-740[7][g]. If greater than half of the sample results for a given nonradionuclide $\mathrm{COC}$ are below detection, the statistical value is set equal to the maximum concentration detected (i.e., versus computing a $95 \% \mathrm{UCL}$ ).

Statistical calculations for $618-3$ verification data are presented in the $95 \% \mathrm{UCL}$ calculation briefs (Appendix $\mathrm{C}$ ), with results shown in Table 2 . The columns on the left side of Table 2 are the COCs and the 95\% statistical values before subtraction of background. The third column of Table 2 presents the background, and the last column presents the statistical values adjusted for background, if appropriate, which becomes the cleanup verification data set used for evaluation against RAGs. All of the COCs for the 618-3 site were detected below background in the verification samples.

\subsection{BIASED SAMPLE RESULTS}

Three biased grab samples were collected at suspect hot spots as determined from post-excavation radiological surveys (Figures 3 and 4).

Statistical analysis (e.g., calculation of a $95 \%$ UCL value) is inappropriate to use for evaluation of biased samples; therefore, the sample results for each biased sample are evaluated using the maximum detected activity of uranium and comparing the value directly to the cleanup level. Table 3 provides a comparison of the maximum result of the three biased samples against the cleanup criteria. Individual sample results are provided in Appendix A. Thorium-228, thorium-230, and thorium-232 were quantified above the minimum detectable activity, but are not considered within Table 3 . These isotopes were detected at levels below statistical background activities based on the assumption of secular equilibrium (the background activity for thorium-228 is less than the statistical background activity of $1.32 \mathrm{pCi} / \mathrm{g}$ for thorium-232 [DOE-RL 1996] and the background activity for thorium-230 is less than the statistical background activity of $1.1 \mathrm{pCi} / \mathrm{g}$ for naturally occurring uranium-238 [DOE-RL 1996]). All isotopic uranium levels were measured below the soil cleanup limits established for the industrial landuse scenario (DOE-RL 2004b) as shown in Table 3. 
CVP-2006-00005

Rev. 0

Table 2. Cleanup Verification Data Set.

\begin{tabular}{|l|c|c|c|}
\hline \multicolumn{1}{|c|}{ COCs } & $\begin{array}{c}\text { 95\% UCL Statistical } \\
\text { Values }^{\mathrm{a}}\end{array}$ & $\begin{array}{c}\text { Hanford Site } \\
\text { Background }\end{array}$ & $\begin{array}{c}\text { Shallow Zone Cleanup } \\
\text { Verification Data Set }\end{array}$ \\
\hline Radionuclide Concentration (pCi/g) \\
\hline Uranium-233/234 & 0.626 & $1.1^{\mathrm{b}}$ & $0(<\mathrm{BG})$ \\
\hline Uranium-235 & $0.170 \mathrm{U}$ & $0.11^{\mathrm{b}}$ & $0.059 \mathrm{U}$ \\
\hline & 0.696 & $1.1^{\mathrm{b}}$ & $0(<\mathrm{BG})$ \\
\hline Arsenic & Nonradionuclide Concentration (mg/kg) & 2.7 \\
\hline Barium & 2.7 & 6.5 & 73.7 \\
\hline Cadmium & 73.7 & 132 & $0.082 \mathrm{U}$ \\
\hline Chromium & $0.082 \mathrm{U}$ & $0.81^{\mathrm{c}}$ & 9.4 \\
\hline Lead & 9.4 & 18.5 & 3.8 \\
\hline Selenium & 3.8 & 10.2 & 0.61 \\
\hline Silver & 0.61 & $0.78^{\mathrm{c}}$ & $0.15 \mathrm{U}$ \\
\hline Uranium (total) & $0.15 \mathrm{U}$ & 0.73 & 1.56 \\
\hline
\end{tabular}

NOTE: All COCs were either not detected or detected below background.

a Laboratory data, including the minimum detectable activity or practical quantitation limit for the individual cleanup verification samples, are included in Appendix A and the 95\% UCL calculation brief in Appendix C.

b DOE-RL, 1996, Hanford Site Background: Part 2, Soil Background for Radionuclides, DOE/RL-96-12, Rev. 0, U.S. Department of Energy, Richland Operations Office, Richland, Washington.

${ }^{c}$ Hanford Site-specific background not available. Value is from Ecology publication 94-115 (Ecology 1994).

$B G=$ background $\quad U$ = undetected

$\mathrm{COC}=$ contaminant of concern $\quad \mathrm{UCL}=$ upper confidence limit

Table 3. Maximum Results from Biased Sampling.

\begin{tabular}{|c|c|c|c|c|}
\hline \multirow{2}{*}{$\begin{array}{c}\text { Contaminant of } \\
\text { Concern }\end{array}$} & $\begin{array}{c}\text { Maximum Result } \\
(\mathrm{pCi} / \mathrm{g})\end{array}$ & \multicolumn{2}{|c|}{$\begin{array}{c}\text { Industrial Land-Use Soil } \\
\text { Cleanup Level } \\
(\mathrm{pCi} / \mathrm{g})\end{array}$} & \multirow{2}{*}{$\begin{array}{c}\text { Does the Maximum Result } \\
\text { Meet the Cleanup Level? }\end{array}$} \\
\cline { 3 - 4 } & 164 & $\begin{array}{c}\text { Direct } \\
\text { Exposure }\end{array}$ & $\begin{array}{c}\text { Groundwater } \\
\text { Protection }\end{array}$ & \\
\hline Total uranium $^{\mathrm{c}}$ & 350 & 267 & Yes \\
\hline
\end{tabular}

${ }^{a}$ Values determined using uranium equilibrium isotopic ratios and the industrial scenario selected soil cleanup levels for total uranium as provided in the Remedial Design Report/Remedial Action Work Plan for the 300 Area (DOE-RL $2004 b)$

b The industrial scenario groundwater protection selected soil cleanup level for total uranium (267 pCi/g) was calculated using RESRAD, based on the generic site model, with a length parallel to groundwater of $100 \mathrm{~m}(328 \mathrm{ft})$ and distribution coefficient values of $8.9 \mathrm{~mL} / \mathrm{g}$ for the contaminated unsaturated zone and $0 \mathrm{~mL} / \mathrm{g}$ for the saturated zone (with no unsaturated, uncontaminated zone) (DOE-RL 2004b).

c Reported total uranium value is based on summation of laboratory-reported isotopic uranium concentrations.

RESRAD = RESidual RADioactivity (dose model) 


\subsection{SITE-SPECIFIC CLEANUP VERIFICATION MODEL}

A site-specific vadose zone model was not developed for the 618-3 site. For the statistical cleanup verification data set, all COCs were either undetected, or determined to be below the statistical background levels, as shown in Table 2. Additionally, the maximum total uranium value $(164 \mathrm{pCi} / \mathrm{g})$ detected in the biased samples is below the established soil cleanup level ( $267 \mathrm{pCi} / \mathrm{g}$ ) for the industrial land-use scenario (Table 3 ).

\subsection{RESRAD MODELING}

A site-specific RESidual RADioactivity (RESRAD) model was not developed for the 618-3 waste site, as the statistical values were determined to be below the statistical background levels as reported in Hanford Site Background: Part 2, Soil Background for Radionuclides (DOE-RL 1996). The maximum residual total uranium activity detected by biased sampling is below the $15 \mathrm{mrem} / \mathrm{yr}$ dose equivalence direct exposure lookup value as established in the ESD (EPA 2004) and documented in the RDR/RAWP (DOE-RL 2004b).

\subsection{EVALUATION OF REMEDIAL ACTION GOAL ATTAINMENT}

This section demonstrates that remedial actions at the 618-3 waste site have achieved the RAGs developed to support industrial land use at the 300 Area as established in the ESD (EPA 2004) and documented in the RDR/RAWP (DOE-RL 2004b).

\subsection{DIRECT EXPOSURE SOIL REMEDIAL ACTION GOALS ATTAINED}

\subsubsection{Radionuclides}

5.1.1.1 Direct Comparison to RAGs. The cleanup verification statistical values for isotopic uranium, the only radionuclide $\mathrm{COC}$, was either not detected or detected below background levels, as shown in Table 2. The maximum total uranium activity $(164 \mathrm{pCi} / \mathrm{g})$ detected in the biased samples is below the direct exposure RAG of $350 \mathrm{pCi} / \mathrm{g}$, the concentration corresponding to a $15 \mathrm{mrem} / \mathrm{yr}$ dose equivalence (EPA 2004, DOE-RL 2004b). All applicable radionuclide RAGs have been met for direct exposure.

5.1.1.2 Radionuclide Risk. Isotopic uranium, the only radionuclide COC, was either not detected or detected below background levels for the statistical verification data set and therefore does not contribute to the residual excess carcinogenic risk for the site. The maximum total uranium activity $(164 \mathrm{pCi} / \mathrm{g})$ detected in the biased samples is below the total uranium lookup value of $350 \mathrm{pCi} / \mathrm{g}$ that satisfies the RAO for cumulative risk $\left(10^{-4}\right.$ to $10^{-6}$ under an industrial land-use scenario) (DOE-RL 2004b). 


\subsubsection{Nonradionuclides}

5.1.2.1 Direct Comparison to RAGs. All nonradionuclide COCs were either not detected or detected below background levels for the statistical verification data set at the 618-3 waste site, as shown in Table 2. Therefore, all applicable RAGs are met.

5.1.2.2 Noncarcinogenic Hazard Quotient RAG Attained. For noncarcinogenic COCs, WAC 173-340-745(a) and (b) specify the evaluation of the hazard quotient. All nonradionuclide COCs were either not detected or detected below background levels for the statistical verification data set; consequently, hazard quotient values were not calculated.

5.1.2.3 Carcinogenic Risk RAG Attained. For individual nonradionuclide carcinogenic COCs, the WAC 173-340-745(4)(a)(iii) Method C cleanup limits are based on an industrial land-use incremental cancer risk of $1 \times 10^{-5}$. The cumulative excess cancer risk for all nonradionuclide carcinogenic COCs must also be less than $1 \times 10^{-5}$ (WAC 173-340). Excess cancer risk was not calculated because the nonradionuclide carcinogenic COCs identified for the 618-3 waste site (arsenic and cadmium) were either not detected or detected below the statistical background levels.

\subsection{GROUNDWATER REMEDIAL ACTION GOALS ATTAINED}

\subsubsection{Radionuclides}

For the statistical verification data set, isotopic uranium was either not detected or detected below statistical background levels and therefore has met the applicable groundwater RAGs. The maximum total uranium activity detected in the biased samples is below the total uranium soil cleanup level $(267 \mathrm{pCi} / \mathrm{g})$ established for the protection of groundwater (21.2 pCi/L) (EPA 2004, DOE-RL 2004b).

\subsubsection{Nonradionuclides}

All nonradionuclide COCs were either not detected or detected below background, as shown in Table 2, and therefore are protective of the groundwater RAGs.

\subsection{COLUMBIA RIVER REMEDIAL ACTION GOALS ATTAINED}

\subsubsection{Radionuclides}

The cleanup verification statistical values for isotopic uranium were either not detected or detected below the statistical background levels and are therefore protective of the Columbia River. The maximum total uranium activity detected in the biased samples is below the total uranium soil cleanup level of $267 \mathrm{pCi} / \mathrm{g}$, which has been determined to be protective of the Columbia River (EPA 2004, DOE-RL 2004b). 


\subsubsection{Nonradionuclides}

All nonradionuclide COCs were either not detected or detected below background levels, as shown in Table 2, and therefore are protective of the Columbia River.

\subsection{WAC 173-340 THREE-PART TEST FOR NONRADIONUCLIDES}

The WAC 173-340-740(7)(e) three-part test is applicable to nonradionuclide COCs and consists of the following criteria: (1) the cleanup verification statistical value must be less than the cleanup level, (2) no single detection can exceed two times the cleanup criteria, and (3) the percentage of samples exceeding the cleanup criteria must be less than $10 \%$. The most restrictive RAG (defined as the lowest of the direct exposure, groundwater protection, and river protection RAGs) is used for the test.

All nonradionuclide COCs were either not detected or detected below the statistical background levels. As such, the 618-3 waste site passes the WAC three-part test and the RAOs for protection of groundwater and the Columbia River have been attained.

\subsection{STATEMENT OF PROTECTIVENESS}

This cleanup verification package demonstrates that remedial action at the 618-3 waste site has achieved the RAOs and corresponding RAGs established for the industrial land-use scenario in the ROD (EPA 2001), the ESD (EPA 2004), and the RDR/RAWP (DOE-RL 2004b). The contaminated materials from the site have been excavated and disposed at ERDF. The remaining soil at the 618-3 site has been sampled, analyzed, and evaluated. Results indicate that the site supports future land uses that can be represented (or bounded) by the industrial land-use scenario and poses no threat to groundwater or the Columbia River. The 618-3 waste site is verified to be remediated in accordance with the ROD (EPA 2001) and the ESD (EPA 2004). This site has no deep zone; therefore, no institutional controls are required.

\subsection{REFERENCES}

40 CFR 141, "National Primary Drinking Water Regulations," Code of Federal Regulations, as amended.

65 FR 76708, "National Primary Drinking Water Regulations; Radionuclides; Final Rule," Federal Register, Vol. 65, No. 236, p. 76708, December 7, 2000. 
BHI, 2001, Calculation of Total Uranium Activity Corresponding to a Maximum Contaminant Level for Total Uranium of 30 Micrograms per Liter in Groundwater, 0100X-CA-V0038, Rev. 0, Bechtel Hanford, Inc., Richland, Washington.

BHI, 2002, Protection of 300 Area Groundwater from Uranium-Contaminated Soils at Remediated Sites, BHI-01667, Rev. 0, Bechtel Hanford, Inc. Richland, Washington.

Comprehensive Environmental Response, Compensation, and Liability Act of 1980, 42 U.S.C. 9601 , et seq.

DOE Order 5400.5, Radiation Protection of the Public and the Environment, U.S. Department of Energy, Washington, D.C.

DOE-RL, 1996, Hanford Site Background: Part 2, Soil Background for Radionuclides, DOE/RL-96-12, Rev. 0, U.S. Department of Energy, Richland Operations Office, Richland, Washington.

DOE-RL, 1998, Tri-Party Agreement Handbook Management Procedures, RL-TPA-90-0001, Guideline Number TPA-MP-14, "Maintenance of the Waste Information Data System (WIDS)," U.S. Department of Energy, Richland Operations Office, Richland, Washington.

DOE-RL, 2000, 100 Area Burial Grounds Focused Feasibility Study, DOE/RL-98-18, Rev. 1, U.S. Department of Energy, Richland Operations Office, Richland, Washington.

DOE-RL, 2004a, 300 Area Remedial Action Sampling and Analysis Plan, DOE/RL-2001-48, Rev. 1, U.S. Department of Energy, Richland Operations Office, Richland, Washington.

DOE-RL, 2004b, Remedial Design Report/Remedial Action Work Plan for the 300 Area, DOE/RL-2001-47, Rev. 1, U.S. Department of Energy, Richland Operations Office, Richland, Washington.

Ecology, 1994, National Background Soil Metals Concentrations in Washington State, Publication 94-115, Washington State Department of Ecology, Olympia, Washington.

Ecology, EPA, and DOE, 1989, Hanford Federal Facility Agreement and Consent Order, 2 vols., as amended, Washington State Department of Ecology, U.S. Environmental Protection Agency, and U.S. Department of Energy, Olympia, Washington. 
EPA, 2001, Interim Action Record of Decision for the 300-FF-2 Operable Unit, Hanford Site, Benton County, Washington, U.S. Environmental Protection Agency, Region 10, Seattle, Washington.

EPA, 2004, Explanation of Significant Differences for the 300-FF-2 Operable Unit Interim Record of Decision, U.S. Environmental Protection Agency, Region 10, Seattle, Washington.

WAC 173-340, 1996, "Model Toxics Control Act - Cleanup" Washington Administrative Code.

WCH, 2006a, Closeout Plan for the 618-3 Burial Ground, CCN 126067, Washington Closure Hanford, Richland, Washington.

WCH, 2006b, Remedial Sampling, Logbook EL-1395-11, Washington Closure Hanford, Richland, Washington. 
CVP-2006-00005

Rev. 0 
CVP-2006-00005

Rev. 0

\section{APPENDIX A}

SUMMARY OF VERIFICATION SOIL SAMPLING AND ANALYTICAL RESULTS 
CVP-2006-00005

Rev. 0 
Table A-1. 618-3 Shallow Zone Cleanup Verification Data. (2 pages)

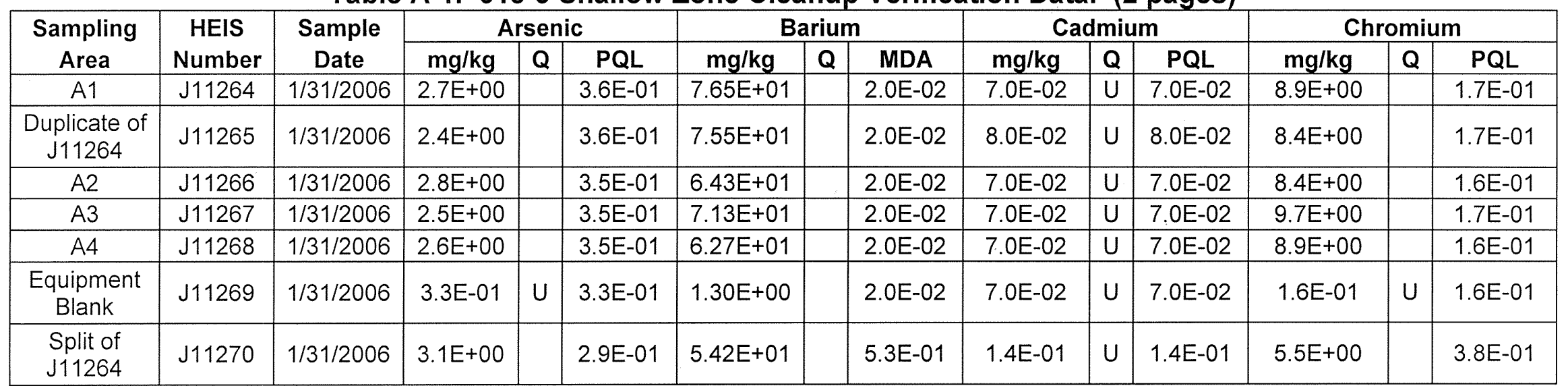

\begin{tabular}{|c|c|c|c|c|c|c|c|c|c|c|c|c|c|c|}
\hline \multirow{2}{*}{$\begin{array}{c}\text { Sampling } \\
\text { Area }\end{array}$} & \multirow{2}{*}{$\begin{array}{c}\text { HEIS } \\
\text { Number }\end{array}$} & \multirow{2}{*}{$\begin{array}{c}\text { Sample } \\
\text { Date }\end{array}$} & \multicolumn{3}{|c|}{ Lead } & \multicolumn{3}{|c|}{ Selenium } & \multicolumn{3}{|c|}{ Silver } & \multicolumn{3}{|c|}{ Uranium (Total) } \\
\hline & & & $\mathrm{mg} / \mathrm{kg}$ & $\mathbf{Q}$ & $P Q L$ & $\mathrm{mg} / \mathrm{kg}$ & $\mathbf{Q}$ & PQL & $\mathrm{mg} / \mathrm{kg}$ & $\mathbf{Q}$ & $P Q L$ & $\mathrm{mg} / \mathrm{kg}$ & $\mathbf{Q}$ & $P Q L$ \\
\hline $\mathrm{A} 1$ & $\mathrm{~J} 11264$ & $1 / 31 / 2006$ & $3.7 E+00$ & & $3.3 E-01$ & $6.5 \mathrm{E}-01$ & & $3.8 \mathrm{E}-01$ & $1.5 \mathrm{E}-01$ & $\mathrm{U}$ & 1.5E-01 & $1.21 \mathrm{E}+00$ & & $1.7 E-02$ \\
\hline $\begin{array}{l}\text { Duplicate of } \\
\text { J11264 }\end{array}$ & J11265 & $1 / 31 / 2006$ & $3.6 \mathrm{E}+00$ & & 3.3E-01 & 4.6E-01 & & 3.9E-01 & 1.5E-01 & $U$ & 1.5E-01 & $1.34 \mathrm{E}+00$ & & 1.7E-02 \\
\hline A2 & $J 11266$ & $1 / 31 / 2006$ & $3.4 E+00$ & & $3.2 \mathrm{E}-01$ & $6.6 \mathrm{E}-01$ & & $3.7 \mathrm{E}-01$ & $1.4 \mathrm{E}-01$ & $\bar{U}$ & 1.4E-01 & $1.61 \mathrm{E}+00$ & & 1.7E-02 \\
\hline A3 & J11267 & $1 / 31 / 2006$ & $3.9 E+00$ & & $3.2 \mathrm{E}-01$ & 4.4E-01 & & $3.8 \mathrm{E}-01$ & $1.5 \mathrm{E}-01$ & $U$ & $1.5 \mathrm{E}-01$ & $1.33 E+00$ & & 1.7E-02 \\
\hline $\mathrm{A} 4$ & J11268 & $1 / 31 / 2006$ & $2.7 \mathrm{E}+00$ & & $3.2 \mathrm{E}-01$ & 4.6E-01 & & 3.7E-01 & $1.4 \mathrm{E}-01$ & $\mathrm{U}$ & 1.4E-01 & $1.51 \mathrm{E}+00$ & & 1.7E-02 \\
\hline $\begin{array}{l}\text { Equipment } \\
\text { Blank }\end{array}$ & J11269 & $1 / 31 / 2006$ & 4.5E-01 & & 3.0E-01 & $3.5 \mathrm{E}-01$ & $U$ & $3.5 \mathrm{E}-01$ & 1.4E-01 & $U$ & 1.4E-01 & 4.49E-01 & & 1.7E-02 \\
\hline $\begin{array}{l}\text { Split of } \\
\text { J11264 }\end{array}$ & J11270 & $1 / 31 / 2006$ & $2.2 E+00$ & & $1.2 \mathrm{E}-01$ & $2.5 E-01$ & B & $1.8 \mathrm{E}-01$ & 2.1E-01 & U & 2.1E-01 & $1.64 \mathrm{E}+00$ & & 2.08E-02 \\
\hline
\end{tabular}

$B=$ analyte found in method blank

HEIS = Hanford Environmental Information System

$\mathrm{MDA}=$ minimum detectable activity

$P Q L=$ practical quantitation limit

$Q=$ qualifier

$U=$ undetected 
Table A-1. 618-3 Shallow Zone Cleanup Verification Data. (2 pages)

\begin{tabular}{|c|c|c|c|c|c|c|c|c|c|c|c|}
\hline Sampling & HEIS & Sample & \multicolumn{2}{|c|}{ Uranium-233/234 } & \multicolumn{2}{c|}{ Uranium-235 } & \multicolumn{2}{c|}{ Uranium-238 } \\
\cline { 7 - 12 } Area & Number & Date & pCi/g & Q & MDA & pCi/g & Q & MDA & pCi/g & Q & MDA \\
\hline A1 & $\mathrm{J} 11264$ & $1 / 31 / 2006$ & $4.47 \mathrm{E}-01$ & & $2.3 \mathrm{E}-01$ & $2.8 \mathrm{E}-01$ & $\mathrm{U}$ & $2.8 \mathrm{E}-01$ & $7.45 \mathrm{E}-01$ & & $2.3 \mathrm{E}-01$ \\
\hline $\begin{array}{c}\text { Duplicate of } \\
\mathrm{J} 11264\end{array}$ & $\mathrm{~J} 11265$ & $1 / 31 / 2006$ & $6.12 \mathrm{E}-01$ & & $2.8 \mathrm{E}-01$ & $3.3 \mathrm{E}-01$ & $\mathrm{U}$ & $3.3 \mathrm{E}-01$ & $5.04 \mathrm{E}-01$ & $2.8 \mathrm{E}-01$ \\
\hline $\mathrm{A} 2$ & $\mathrm{~J} 11266$ & $1 / 31 / 2006$ & $5.23 \mathrm{E}-01$ & & $1.9 \mathrm{E}-01$ & $2.3 \mathrm{E}-01$ & $\mathrm{U}$ & $2.3 \mathrm{E}-01$ & $7.47 \mathrm{E}-01$ & & $1.9 \mathrm{E}-01$ \\
\hline $\mathrm{A} 3$ & $\mathrm{~J} 11267$ & $1 / 31 / 2006$ & $6.77 \mathrm{E}-01$ & & $2.5 \mathrm{E}-01$ & $3.0 \mathrm{E}-01$ & $\mathrm{U}$ & $3.0 \mathrm{E}-01$ & $5.48 \mathrm{E}-01$ & $2.5 \mathrm{E}-01$ \\
\hline $\mathrm{A} 4$ & $\mathrm{~J} 11268$ & $1 / 31 / 2006$ & $5.23 \mathrm{E}-01$ & & $2.9 \mathrm{E}-01$ & $3.5 \mathrm{E}-01$ & $\mathrm{U}$ & $3.5 \mathrm{E}-01$ & $4.48 \mathrm{E}-01$ & $2.9 \mathrm{E}-01$ \\
\hline Equipment Blank & $\mathrm{J} 11269$ & $1 / 31 / 2006$ & $1.90 \mathrm{E}-01$ & $\mathrm{U}$ & $2.9 \mathrm{E}-01$ & $0.0 \mathrm{E}+00$ & $\mathrm{U}$ & $3.5 \mathrm{E}-01$ & $1.90 \mathrm{E}-01$ & $\mathrm{U}$ & $2.9 \mathrm{E}-01$ \\
\hline Split of J11264 & $\mathrm{J} 11270$ & $1 / 31 / 2006$ & $1.09 \mathrm{E}+00$ & & $2.13 \mathrm{E}-02$ & $3.78 \mathrm{E}-02$ & & $3.77 \mathrm{E}-02$ & $1.07 \mathrm{E}+00$ & $2.13 \mathrm{E}-02$ \\
\hline
\end{tabular}

Table A-2. Verification Sample Results (Biased Samples).

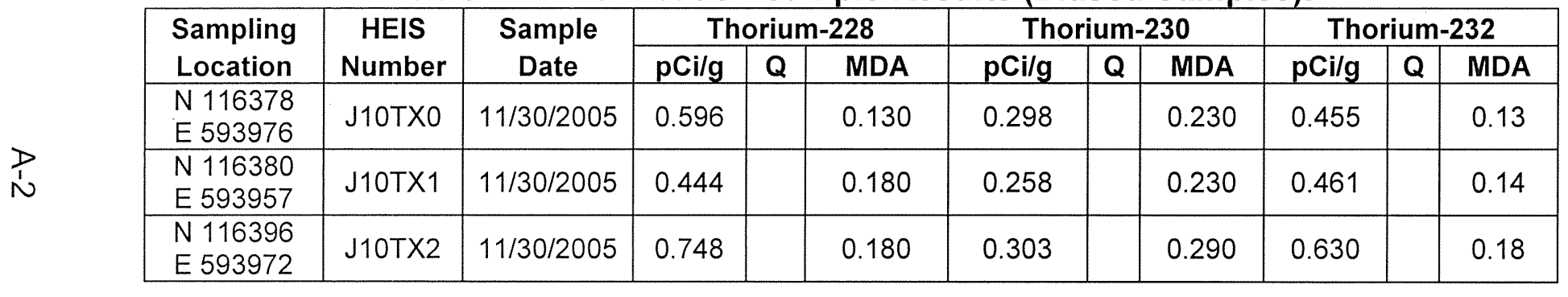

\begin{tabular}{|c|c|c|c|c|c|c|c|c|c|c|c|c|c|c|}
\hline \multirow{2}{*}{$\begin{array}{l}\text { Sampling } \\
\text { Location }\end{array}$} & \multirow{2}{*}{$\begin{array}{c}\text { HEIS } \\
\text { Number }\end{array}$} & \multirow{2}{*}{$\begin{array}{c}\text { Sample } \\
\text { Date }\end{array}$} & \multicolumn{3}{|c|}{ Uranium-233/234 } & \multicolumn{3}{|c|}{ Uranium-235 } & \multicolumn{3}{|c|}{ Uranium-238 } & \multicolumn{3}{|c|}{ Uranium (Total) $^{\mathrm{a}}$} \\
\hline & & & $\mathrm{pCi} / \mathrm{g}$ & $\mathbf{Q}$ & MDA & $\mathrm{pCi} / \mathrm{g}$ & $\mathbf{Q}$ & MDA & $\mathrm{pCi} / \mathrm{g}$ & $\mathbf{Q}$ & MDA & $\mathrm{pCi} / \mathrm{g}$ & $\mathbf{Q}$ & $M A^{b}$ \\
\hline $\begin{array}{l}\text { N } 116378 \\
E 593976 \\
\end{array}$ & J10TX0 & $11 / 30 / 2005$ & 79.6 & & 0.55 & 4.79 & & 0.22 & 79.4 & & 0.52 & 164 & & 0.43 \\
\hline $\begin{array}{l}\text { N } 116380 \\
E 593957 \\
\end{array}$ & J10TX1 & $11 / 30 / 2005$ & 27.5 & & 0.28 & 1.45 & & 0.17 & 25.4 & & 0.28 & 54.4 & & 0.24 \\
\hline $\begin{array}{l}N 116396 \\
E 593972\end{array}$ & J10TX2 & $11 / 30 / 2005$ & 11.8 & & 0.18 & 0.432 & & 0.17 & 11.9 & & 0.18 & 24.1 & & 0.18 \\
\hline
\end{tabular}

${ }^{a}$ Reported total uranium value is based on summation of laboratory-reported isotopic uranium concentrations.

${ }^{b}$ Reported MDA is calculated as the average of laboratory-reported isotopic MDA values. 
CVP-2006-00005

Rev. 0

APPENDIX B

DATA QUALITY ASSESSMENT

B-i 
CVP-2006-00005

Rev. 0 


\section{B1.0 DATA QUALITY ASSESSMENT FOR THE 618-3 BURIAL GROUND WASTE SITE}

\section{B1.1 OVERVIEW}

The data quality assessment (DQA) completes the data life cycle (i.e., planning, implementation, and assessment) that was initiated by the data quality objectives process. The DQA includes a review of the field logbook information (WCH 2006c) to verify sample location, date, and time. It also involves a scientific and statistical evaluation of the data to determine if they are of the right type, quality, and quantity to support their intended use for closeout decisions (EPA 2000).

This DQA was performed in accordance with WCH-EE-01, Environmental Investigations Procedures. Specific data quality objectives for the site are found in the 300 Area Remedial Action Sampling and Analysis Plan (SAP) (DOE-RL 2004a). The DQA is based on the guidelines presented in Guidance for Data Quality Assessment (EPA 2000). Statistical tests used in this DQA were performed as specified in the SAP and the Remedial Design Report/Remedial Action Work Plan for the 300 Area (RDR/RAWP) (DOE-RL 2004b).

Prior to performing statistical tests, the field logbook (WCH 2006c), sample designs (WCH 2006b), and sample analytical data are evaluated. A portion of the cleanup verification sample analytical data are validated for compliance requirements (DOE-RL 2004a). Data evaluation is performed to determine if the laboratory carried out all steps required by the SAP and the laboratory contract governing the conduct of analysis and reporting of the data. This evaluation also examines the available laboratory data to determine if an analyte is present or absent in a sample and the degree of overall uncertainty associated with that determination. Data validation is done in accordance with validation procedures (BHI 2000a, 2000b) as part of data evaluation. After data evaluation and validation, the appropriate statistical analyses are performed on the adjusted raw analytical data (Appendix $\mathrm{C}$ ) to determine statistical values for each contaminant. The cleanup verification sample analytical data are stored in the Environmental Restoration database prior to archiving in the Hanford Environmental Information System and are summarized in Appendix A.

\section{B1.2 LABORATORY QUALITY MEASURES}

All verification samples are subject to laboratory-specific quality assurance (QA) requirements, including instrument procurement, maintenance, calibration, and operation. Additional laboratory quality control $(\mathrm{QC})$ checks are performed, as appropriate, for the analytical method at a rate of 1 per sample delivery group (SDG), or 1 in 20, whichever is more frequent. Laboratory internal QC checks include the following: 
- Laboratory Contamination. Each analytical batch contains a laboratory (method) blank (material of similar composition as the samples with known/minimal contamination of the analytes of interest) carried through the complete analytical process. The method blank is used to evaluate false-positive results in samples due to contamination during handling at the laboratory.

- Analytical Accuracy. For most analyses, a known quantity of representative analytes of interest (matrix spike/matrix spike duplicate [MS/MSD]) is added to a separate aliquot of a sample from the analytical batch. The recovery percentage of the added MS is used to evaluate analytical accuracy. For analyses not amenable to MS techniques (e.g., gamma energy analysis) or where analytical recovery is corrected via internal standards (e.g., alpha spectral analyses), accuracy is evaluated from recovery of the QC reference sample (e.g., laboratory control spike or blank spike sample).

- Analytical Precision. Separate aliquots removed from the same sample container (replicate samples) are analyzed for each analytical batch. The replicate sample results (evaluated as relative percent differences [RPDs]) are used to assess analytical precision.

- QC Reference Samples. A QC reference sample is prepared from an independent standard at a concentration other than that used for calibration, but within the calibration range. Reference samples provide an independent check on analytical technique and methodology.

Laboratories are also subject to periodic and random assessments of the laboratory performance, systems, and overall program. These assessments are performed by the Washington Closure Hanford QA group to ensure that the laboratories are performing within laboratory contract requirements.

\section{B1.3 DATA VALIDATION}

After sampling was completed, all of the fixed-base laboratory data from SDG K0204 were submitted for third party validation, to Level C per WCH-EE-01, Procedure 2.5, "Data Package Validation Process." Level C validation procedures are specified in Data Validation Procedure for Radiochemical Analysis (BHI 2000b) and Data Validation Procedure for Chemical Analysis (BHI 2000a).

Use of Level C validation procedures was included in the review of the following items, as appropriate, for each analytical method:

- Sample holding times

- Method blanks

- MS/MSD recovery

- Surrogate recovery 
- Sample replicates

- Associated batch laboratory control sample results

- Data package completeness

- Achievement of required (or contractual) detection limits (RDLs).

Data flagged by the validator as estimated (i.e., "J") indicate that the associated concentration is an estimate, but that the data may be used for decision-making purposes. Data flagged as below detection limits (i.e., "U") indicate the contaminant was analyzed for but not detected, and the concentration is below the minimum detectable activity (MDA) for radionuclides or the practical quantitation limit (PQL) (i.e., reporting limit) for nonradionuclides. For nonradionuclides, nondetects are reported at the PQL. For radionuclides, nondetects report the actual value obtained from analysis (positive or negative but less than the MDA) except for limited analyses where no value can be calculated. In these cases, the MDA is reported. This situation is applicable for sample results that are below detection limits. All other validated results are considered accurate within the standard errors associated with the methods.

The adequacy of laboratory QA/QC was evaluated for precision, accuracy, completeness, and RDLs pursuant to the SAP (DOE-RL 2004a). The organization performing the data validation reported that, of the data given formal validation, the laboratory met the standards for performance for precision $( \pm 30 \%)$, accuracy $( \pm 30 \%)$, and completeness $(>90 \%)$. Comparison of the RDL with the respective MDA or PQL is discussed in Section B1.4.

The validated SDG K0204 contains six samples (J11264, J11265, J11266, J11267, J11268, and J11270) and an equipment blank (J11269) from the 618-3 Burial Ground. Sample J11265 is a duplicate of sample J11264. A summary of deficiencies noted during validation follows.

- Radionuclides. The validation DQA noted no major deficiencies.

Total uranium was found in the equipment blank (J11269) at $0.449 \mathrm{mg} / \mathrm{kg}$. The Hanford Site-specific background value for total uranium is $3.21 \mathrm{mg} / \mathrm{kg}$. This result is probably carryover in the analytical equipment but does not represent a significant source of contamination. The field sample data are useable for decision-making purposes.

- Nonradionuclides. The validation DQA noted no major deficiencies.

Barium and lead were found in the equipment blank (J11269) at $1.3 \mathrm{mg} / \mathrm{kg}$ and $0.45 \mathrm{mg} / \mathrm{kg}$, respectively. This result does not represent a significant source of contamination relative to the lowest applicable RAGs $(132 \mathrm{mg} / \mathrm{kg}$ and $10.2 \mathrm{mg} / \mathrm{kg}$, respectively). The field sample data are useable for decision-making purposes. 


\section{B1.4 LABORATORY DATA EVALUATION}

The following paragraphs include a data evaluation of three verification sample SDGs for the 618-3 Burial Ground, SDG K0137, SDG K0204, and SDG J00056. SDG K0137 consists of three biased samples (J10TX0, J10TX1, J10TX2). SDG K0204 consists of six total samples (J11271 through J11276) from the 618-3 site, four statistical samples, an equipment blank (J11276), and a field duplicate (J11272). SDG K0204 was also subjected to third-party verification, as mentioned above. SDG J00056 consists of one split sample (J11277).

The context for assessing the data includes evaluating the sample data using the statistical methodology of the SAP (DOE-RL 2004a) (included in the calculation briefs in Appendix $\mathrm{C}$ ) and a comparison of analytical results to the parameters as specified in the SAP. This section summarizes the results of the comparison and presents an evaluation of the affected data.

\section{MAJOR DEFICIENCIES}

Any data anomaly that causes final data to be qualified as rejected ("R" flagged) is considered a major deficiency. No major deficiencies were identified in the data.

\section{MINOR DEFICIENCIES}

Sample Holding Times. All of the method-specific holding times were met for all samples in the 618-3 data set.

Method Blanks. The method blank is used to evaluate false-positive results in samples due to contamination during handling at the laboratory.

Radionuclides. In the radionuclide analyses, low-level positive results were observed for uranium-233/234 at $0.035 \mathrm{pCi} / \mathrm{g}$. The Hanford specific background activity for uranium-233/234 is $1.1 \mathrm{pCi} / \mathrm{g}$. Most radiological analytical techniques are counting methods. Due to the nature of this type of analysis, positive, but insignificant, results are not uncommon in the method blank and are not considered contamination.

Nonradionuclides. Barium was detected in the method blank at $0.09 \mathrm{mg} / \mathrm{kg}$. The lowest applicable remedial action goal (RAG) for barium is the river protection RAG at $132 \mathrm{mg} / \mathrm{kg}$. All of the nonradiological method blanks associated with $618-3$ were found acceptable.

MS/MSDs Recoveries. Recovery of spiked analytes in the MS/MSD pair is used to evaluate method efficiency and the effect of the matrix on an environmental sample. 
Radionuclides. All MS/MSD recoveries for radionuclide analytes were within acceptance criteria.

Nonradionuclides. In the inductively coupled plasma metals analysis of SDG J00056 the percent recoveries for barium and chromium were $148 \%$ and $128 \%$, respectively. The barium result is outside of the project-specific acceptance criteria of $+/-30 \%$. The chromium result is outside of the laboratory acceptance criteria of $+/-20 \%$ but is within the project-specific acceptance criteria. Both results are attributed to natural heterogeneity in the soil sample used as the matrix. The data are useable for the intended purpose.

RDL Comparison. Reported analytical detection levels for nondetected analytes were compared to the RDLs specified in the SAP (DOE-RL 2005a). When detected results were obtained, evaluation of detection limits was not performed. The data validation and supplemental data evaluation noted any analyses in which the detection limit (MDA or PQL) was above the SAP RDLs for nondetected analytes.

Radionuclides. All of the reported MDAs are sufficiently low for decision-making purposes. All values meet the site cleanup criteria as demonstrated in the calculation briefs (Appendix $\mathrm{C}$ ) and discussed in this cleanup verification package.

Nonradionuclides. All of the reported method detection limits are less than applicable RAGs, and the data are of sufficient quality for decision-making purposes.

Precision and Accuracy Evaluation. Analytical accuracy and precision were evaluated by examination of the RPD of the main, duplicate, and split samples. Only the contaminants of concern (COCs) detected at five times the target detection limit (or greater) are used for data analysis with respect to accuracy and precision.

Radionuclides. RPDs for the radionuclide analytes were not calculated because an evaluation of the data shows none of the analytes were detected in both the main and duplicate (or split) sample at more than five times the target detection limit.

Nonradionuclides. RPDs for the nonradionuclide analytes barium and chromium were calculated for both the duplicate and split sample. In the duplicate sample analysis, both barium and chromium were within acceptance criteria with RPDs of $1.3 \%$ and $5.8 \%$, respectively. The RPDs for the split sample analysis of barium and chromium were $34 \%$ and $47 \%$, respectively. The acceptance criteria for split sample RPDs is $35 \%$. It was previously discussed that barium and chromium also had high matrix spike recoveries. All of the sample extracts associated with these results were produced using field-collected materials.

The natural heterogeneity of field-collected soils and materials adds to elevated RPDs, such as those listed above. This variability is expected and does not indicate a problem with the analytical system. RPDs of analytes detected at low concentrations (less than 
five times the detection limit) are also not considered to be indicative of the analytical system performance. The data are useable for decision-making purposes.

\section{B1.5 FIELD QUALITY ASSURANCE/QUALITY CONTROL}

Field QA/QC measures were used to assess potential sources of error and cross contamination of soil samples that could bias results. Field QA/QC samples listed in the field logbook (WCH 2006c) are summarized in Table B-1. All main and QA/QC sample results are presented in Appendix $A$.

Table B-1. Summary of Field Quality Control Samples.

\begin{tabular}{|c|c|c|c|}
\hline Equipment Blank & Main Sample & Duplicate & Split \\
\hline $\mathrm{J} 11269$ & $\mathrm{~J} 11264$ & $\mathrm{~J} 11265$ & $\mathrm{~J} 11270$ \\
\hline
\end{tabular}

Field duplicate samples were collected to provide a relative measure of the degree of local heterogeneity in the sampling medium, unlike laboratory duplicates that are used to evaluate precision in the analytical process. The field duplicates are evaluated by computing the RPD of the duplicate samples for each COC. Only analytes with values above five times the detection limits for both the main and duplicate samples are compared. The 95\% upper confidence limit (UCL) calculation briefs (WCH 2006a) in Appendix $\mathrm{C}$ provide details on duplicate pair evaluation and RPD calculation. The data are suitable for the intended purpose of cleanup verification.

Split samples were collected to provide a relative measure of the degree of variability in the sampling, sample handling, and analytical techniques used by commercial laboratories. The field main and split samples are evaluated by computing the RPD of the split samples for each $\mathrm{COC}$ to determine the usability of the verification data. The U.S. Environmental Protection Agency Contract Laboratory Program duplicate sample comparison methodology, USEPA Contract Laboratory Program National Functional Guidelines for Inorganic Data Review (EPA 1994), is used as an initial test of the data from the splits. Only analytes that had values above five times the contractual RDL for both the main and split sample were compared. The 95\% UCL calculation briefs in Appendix $C$ provide details on split pair RPD calculation. These results are typical of the heterogeneity found in the sample matrices and do not indicate a problem in the analytical systems.

\section{B1.6 SUITABILITY OF DATA}

The DQA for the 618-3 determined that the data are of the right type, quality, and quantity to support site cleanup verification decisions within specified error tolerances. The evaluation verified that the sample design was sufficient for the purpose of clean 
site verification. All analytical data were found to be acceptable for decision-making purposes.

\section{B2.0 REFERENCES}

BHI, 2000a, Data Validation Procedure for Chemical Analysis, BHI-01435, Rev. 0, Bechtel Hanford, Inc., Richland, Washington.

BHI, 2000b, Data Validation Procedure for Radiochemical Analysis, BHI-01433, Rev. 0, Bechtel Hanford, Inc., Richland, Washington.

DOE-RL, 2004a, 300 Area Remedial Action Sampling and Analysis Plan, DOE/RL-2001-48, Rev. 1, U.S. Department of Energy, Richland Operations Office, Richland, Washington.

DOE-RL, 2004b, Remedial Design Report/Remedial Action Work Plan for the 300 Area, DOE/RL-2001-47, Rev. 1, U.S. Department of Energy, Richland Operations Office, Richland, Washington.

EPA, 1994, USEPA Contract Laboratory Program National Functional Guidelines for Inorganic Data Review, EPA 540/R-94/013, U.S. Environmental Protection Agency, Washington, D.C.

EPA, 2000, Guidance for Data Quality Assessment, EPA QA/G-9, QA00 Update, U.S. Environmental Protection Agency, Office of Environmental Information, Washington, D.C.

WCH, 2006a, 618-3 Burial Ground Cleanup Verification 95\% UCL Calculations, 0600X-CA-V0057, Rev. 0, Washington Closure Hanford, Richland, Washington.

WCH, 2006b, Closeout Plan for the 618-3 Burial Ground, CCN 126067, Washington Closure Hanford, Richland, Washington.

WCH, 2006c, Remedial Sampling, Logbook EL-1395-11, Washington Closure Hanford, Richland, Washington.

WCH-EE-01, Environmental Investigations Procedures, Washington Closure Hanford, Richland, Washington. 
CVP-2006-00005

Rev. 0 
CVP-2006-00005

Rev. 0

APPENDIX C

CALCULATION BRIEF EXCERPTS

C-i 
CVP-2006-00005

Rev. 0

\section{DISCLAIMER FOR CALCULATIONS}

The calculations that are provided in the following appendix have been generated to document compliance with established cleanup levels. These calculations should be used in conjunction with other relevant documents in the administrative record. 


\section{CALCULATION BRIEFS}

The following calculation briefs have been prepared in accordance with ENG-1, Engineering Services, ENG-1-4.5, "Project Calculations," Washington Closure Hanford, Richland, Washington.

WCH, 2006, 618-3 Burial Ground Cleanup Verification 95\% UCL Calculations, Calculation No. 0600X-CA-V0057, Rev. 0, Washington Closure Hanford, Richland, Washington.

WCH, 2006, 618-3 Shallow Zone Sampling Plan, 0300X-CA-V0066, Rev. 0, Washington Closure Hanford, Richland, Washington.

NOTE: The calculation briefs referenced in this appendix are kept in the active Washington Closure Hanford project files and are available upon request. When the project is completed, the files will be stored in a U.S. Department of Energy, Richland Operations Office repository. 
CVP-2006-00005

Rev. 0

C-2 
CALCULATION COVER SHEET

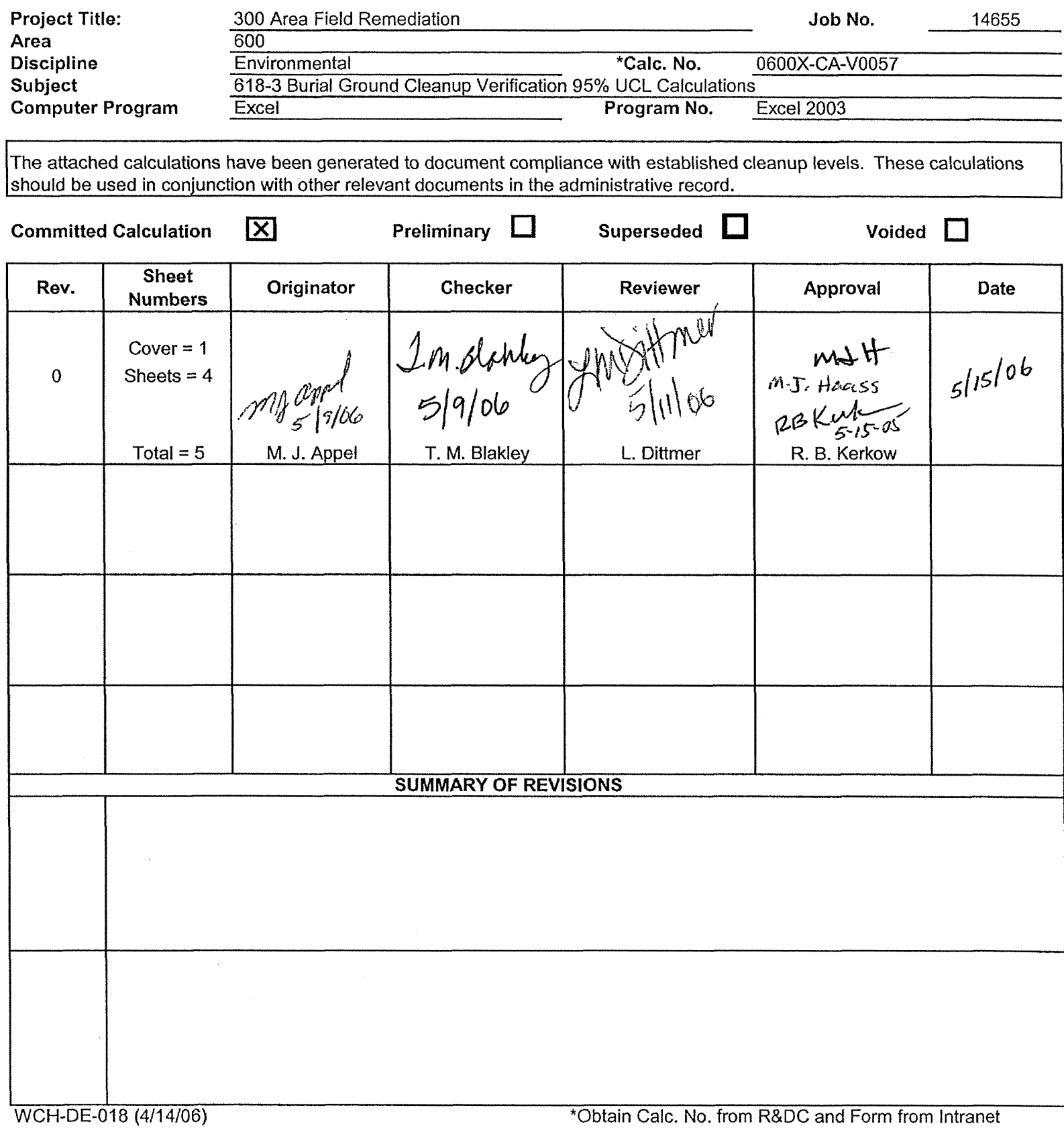


CVP-2006-00005

Rev. 0

Washington Closure Hanford

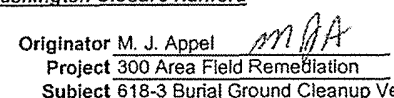

mary

1 Summary

2 Calculate the $95 \%$ upper confidence limit (UCL) to evaluate compliance with cleanup standards for the subject site. Also, calculate the carcinogenic risk for applicable nonradionuclide

2 Calculate the $95 \%$ upper confidence limit (UCL) to evaluate compliance with cleanup standards for the subject site. Also, calculate the carcinogenic risk for applicable nonradionuclide
3 analytes, perform the Washington Administrative Code (WAC) 173-340 (Model Toxics Control Act [MTCA]) 3-part test, if required, and calculate the relative percent difference (RPD) for 4 each contaminant of concern (COC)

6

Table of Contents:

Sheets 1 to 2 - Calculation Sheet Summary

Sheet 3 . Calculation Sheet Shallow Zone Verification

Sheet 4 - Calculation Sheet Split-Duplicate Analysis

Given/References:

1) Sample Results.

1) Sample Results.

3) All lookup values and remedial action goals (RAGS), and background values are taken from DOE-RL (2001), DOE-RL (2004b), or Ecology (1994) unless stated otherwise.

3) DOE-RL, 2001, Hanford Site

7 4) DOE-RL, 2004a, 300 Area Remedial Action Sampling and Analysis Plan (SAP), DOE/RL-2001-48 Rev. 1, U.S. Department of Energy, Richland Operations Office, Richland, Washington.

5) DOE-RL, 2004b, Remedial Design Report/Remedial Action Work Plan for the 300 Area (RDR/RAWP), DOE/RL-2001-47, Rev. 1, U.S. Department of Energy, Richland Operations Office, Richland, Washington.

6) Ecology, 1992, Statistical Guidance for Ecology Site Managers, Publication \#92-54, Washington State Department of Ecology, Olympia, Washington.

7) Ecology, 1993, Statistical Guidance for Ecology Site Managers, Supplement S-6, Anatyzing Site or Background Data with Below-Detection Limit or Below-PQL

Values (Censored Data Sets). Publication $\$ 92-54$, Washington State Department of Ecology, Olympia, Washington.

8) Ecology, 1994, Natural Background Soil Metals Concentrations in Washington State, Publication No. 94-115, Washington State Department of Ecology, Olympia,

Washington.

9) EPA, 1994, USEPA Contract Laborafory Program National Functional Guidelines for inorganic Data Review, EPA 540/R-94/013, U.S. Environmental Protection Agency, Washington, D.C.

0) WAC 173-340, 1996, "Model Toxics Control Act-Cleanup," Washington Administrative Code.

Solution:

Calculation methodology is described in Ecology Pub. \#92-54 (Ecology 1992, 1993), below, and in the RDRRAWP (DOE-RL 2004b). Use data from the attached worksheets to calculate the $95 \% \mathrm{UCL}$, hazard quotients, excess carcinogenic risk, perform the WAC 173-340 3-part test for nonradionuclides, and calculate the RPD for each COC in the primaryduplicate and primary-split sample pairs.

Calculation Description:

The subject calculations were performed on data from sol verification samples from the 618-3 Burial Ground. The data were entered into an EXCEL 2003 spreadsheet and calculations performed by utilizing the built-in spreadsheet functions and/or creating formulae within the cells. The statistical evaluation of data for use in accordance with the RDR/RAWP (DOE-RL 120046

42 site.

44 Methodology:

45 For nonradioactive analytes with $<50 \%$ of the data below detection limits and all radionuclide analytes, the statistical value calculated to evaluate the effectiveness of cleanup is the $46.95 \%$ UCL. For nonradioactive analytes with $>50 \%$ of the data below detection limits, the maximum value for the data set is used instead of the $95 \%$ UCL. All nonradionuclide data 47 reported as being below detection limits are set to $1 / 2$ the detection limit value for calculation of the statistics (Ecology 1993). For radionuclide data, calculation of the statistics was done 48 on the reported value. In cases where the laboratory does not report a value below the minimal detectable activity (MDA), half of the MDA is used in the calculation. For the statistical 49 evaluation of primary-duplicate sample pairs, the samples are averaged before being included in the data set, after adjustments for censored data as described above.

For nonradionuclides, the WAC 173-340 statistical guidance suggests that a test for distributional form be performed on the data and the $95 \%$ UCL calculated on the appropriate 52 distribution using Ecology software. For nonradionuclide small data sets $(n<10)$ and all radionuclide data sets, the calculations are performed assuming nonparametric distribution, so 53 no test for distribution is performed. For nonradionuclide data sets of ten or greater, distributional testing is done using Ecology's MTCAStat software (Ecology 1993). Background 54 values are subtracted for applicable radionuclides only. Comparison against background levels for nonradionuclides is included within the CVP.

56

7 The hazard quotient (for shallow zone nonradionuclide COCs) is determined by dividing the statistical value (derived in this calculation) by the WAC 173-340 non-carcinogenic cleanup 58 limit. The excess nonradionuclide carcinogenic risk is determined by dividing the statistical value by the WAC $173-340$ carcinogenic cleanup limit and then multiplying by $10^{6}$.

60 The WAC 173-340 3-part test is performed for nonradionuclide analytes only and determines if:

61 1) the $95 \%$ UCL value exceeds the most stringent cleanup limit for each non-radionuclide $\mathrm{COC}$

62 2) greater than $10 \%$ of the raw data exceed the most stringent cleanup limit for each non-radionuclide $\mathrm{COC}$

63 3) the maximum value of the raw data set exceeds two times the most stringent cleanup limit for each non-radionuclide $C O C$

65

65 The RPD is calculated when both the primary value and either the duplicate or split values are above detection limits and are greater than 5 times the target detection limit (TDL). The TDL is a laboratory detection limit pre-determined for each analytical method, listed in Table II-1 of the SAP (DOE-RL 2004a). The RPD calculations use the following formula: RPD $=[|M-S|(M+S) / 2)]^{* 100}$

69
70
71

72 For quality assurancelquality control (QAVC) split and duplicate RPO calculations, a value less than $+1-30 \%$ indicates the data compare favorably. For regulatory splits, a threshold of $7335 \%$ is used (EPA 1994). If the RPD is greater than $30 \%$ (or $35 \%$ for regulatory split data), further investigation regarding the usabilty of the data is performed. Additional discussion a 74 necessary is provided in the data quality assessment section of the applicable CVP.

76 If regulator split comparison is required, an additional parameter is evaluated. A control limit of $+l-2$ times the TDL shall be used if either the main or regulator split value is less than 5 77 times the TDL and above detection. In the case where only one result is greater than 5 times the TDL and the other is below, the $+/-2$ times the TDL criterla applies. Therefore, the

8 following calculation is performed as part of the evaluation for these two cases involving regulator split data: difference = main - fegulator split. If the difference is greater than $+1-2$ 
CVP-2006-00005

Rev. 0

Washington Closure Hanford

Originator M. J.Appel MMA Project 300 Area Field Reinediation Job No. 14655 Subject $618-3$ Burial Ground Cleanup Verification $95 \%$ UCL Calculations
Calc. No. 0600X-CA-V0057 Checked T. M. Blakley Jurs
Rev. No. $\frac{0}{S / g /(0)}$

Date $\frac{0}{5 / 9 / 26}$

Summary (continued)

1 Results:

2 The results presented in the summary tables that follow are for use in the 618-3 CVP

$4 \quad$ Results Summary

\begin{tabular}{|c|c|c|c|}
\hline \multirow{2}{*}{ Analyte } & \multicolumn{2}{|c|}{ Shallow Zone } & \multirow{2}{*}{ Units } \\
\hline & Result & Qualifier & \\
\hline Arsenic & $2.7 E+00$ & & $\mathrm{mg} / \mathrm{kg}$ \\
\hline Barium & $7.37 E+01$ & & $\mathrm{mg} / \mathrm{kg}$ \\
\hline Cadmium & $8.0 \mathrm{E}-02$ & $U$ & $\mathrm{mg} / \mathrm{kg}$ \\
\hline Chromium & $9.4 \mathrm{E}+00$ & & $\mathrm{mg} / \mathrm{kg}$ \\
\hline Lead & $3.8 \mathrm{E}+00$ & & $\mathrm{mg} / \mathrm{kg}$ \\
\hline Selenium & $6.1 \mathrm{E}-01$ & & $\mathrm{mg} / \mathrm{kg}$ \\
\hline Silver & $1.5 E-01$ & $\mathrm{U}$ & $\mathrm{mg} / \mathrm{kg}$ \\
\hline Uranium (Total) & $1.56 \mathrm{E}+00$ & & $\mathrm{mg} / \mathrm{kg}$ \\
\hline Uranium-233/234 & $0(<B G)$ & & pCilg \\
\hline Uranium-235 & $5.9 E-02$ & U & $\mathrm{pCi} / \mathrm{g}$ \\
\hline Uranium-238 & $0(<B G)$ & & $\mathrm{pCl} / \mathrm{g}$ \\
\hline
\end{tabular}

18

19 WAC 173-340 Evaluation (Shallow Zone)

20

21 3-Part Test:

$2295 \%$ UCL > Cleanup Limit? NO

$23>10 \%$ above Cleanup Limit? NO

24 Any sample $>2 \times$ Cleanup Limit? NO

26 Risk Estimate:

27 Nonrad noncarcinogenic index sum: 0

28 Nonrad carcinogenic risk:

29

31 Relative Percent Difference Results* QAVQC Analysis

\begin{tabular}{|c|c|c|c|}
\hline \multirow{2}{*}{\multicolumn{2}{|c|}{ Analyte }} & \multicolumn{2}{|c|}{ Shallow Zone } \\
\hline & & $\begin{array}{l}\text { Duplicate } \\
\text { Analysis }\end{array}$ & $\begin{array}{c}\text { Split } \\
\text { Analysis }\end{array}$ \\
\hline 34 & Arsenic & & \\
\hline 35 & Barium & $1.3 \%$ & $34 \%$ \\
\hline 36 & Cadmium & & \\
\hline 37 & Chromium & $5.8 \%$ & $47 \%$ \\
\hline 38 & Lead & & \\
\hline 39 & Selenium & & \\
\hline 40 & Silver & & \\
\hline 41 & Uranium (Total) & & \\
\hline 42 & Uranium-233/234 & & \\
\hline 43 & Uranium-235 & & \\
\hline 44 & Uranium-238 & & \\
\hline
\end{tabular}

45 *A blank cell indicates that RPD evaluation was not required.

46 *"The significance of the reported RPD values, including values greater than $30 \%$, is addressed within the Data Quality Assessment section of the CVP for this site.

47 QAQC = quality assurance/quality control

$48 \mathrm{RPD}=$ relative percent difference

$49 \mathrm{U}=$ undetected 
CVP-2006-00005

Rev. 0

C-6 


\section{Washington Closure Hanford}

Originator M.J. Appel $M / f y$

subject 618-3 Burrial Ground Cleanup Verification $95 \%$ UCL Calculations

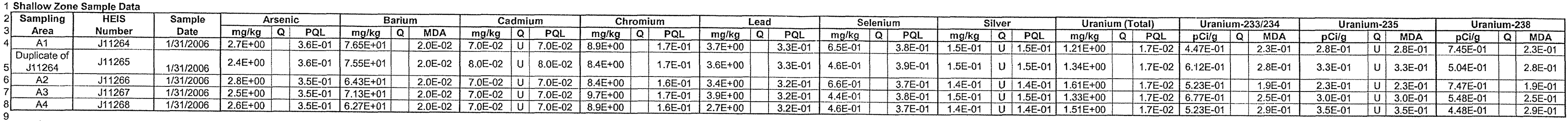

\section{Statistical Computation Input Data}

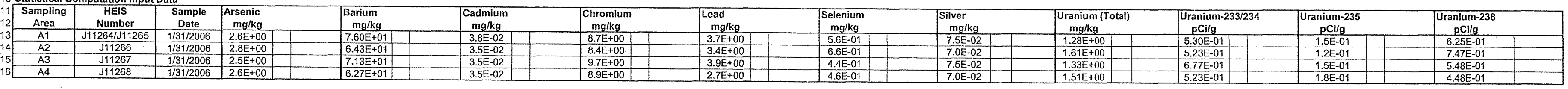

77 Statistical Computations
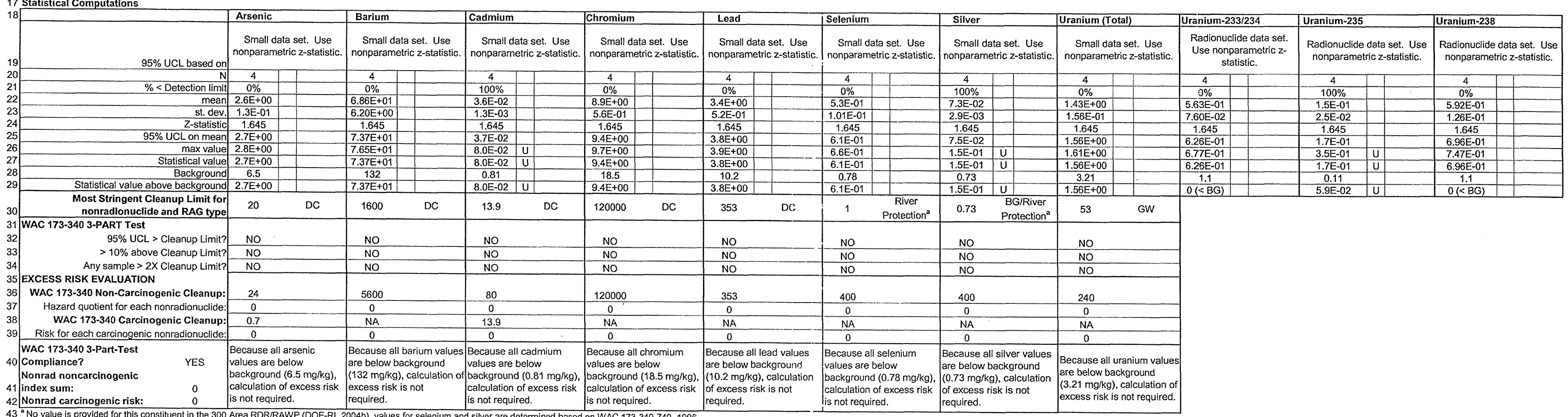

\begin{tabular}{|l|l|l|}
\hline NO & NO & NO \\
\hline NO & No & No \\
\hline NO & NO & NO \\
\hline & &
\end{tabular}

\begin{tabular}{|l|l|l|l|l|}
\hline NO & NO & No & \multirow{2}{*}{ Protection $^{2}$} \\
\hline NO & NO & NO \\
\hline
\end{tabular}

53

ow

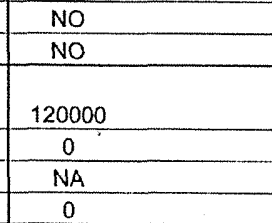

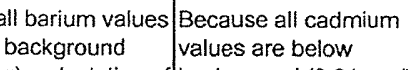

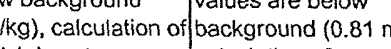

Because all chromium Because all lead values

ackground (18.5 mglkg)

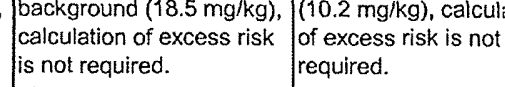
is not required. cuired. UCL = upper confidence limit
WAC $=$ Washington Administrative

\begin{tabular}{|l|l|}
\hline NO & NO \\
\hline NO & NO \\
\hline NO & NO \\
\hline 400 & 240 \\
\hline &
\end{tabular}

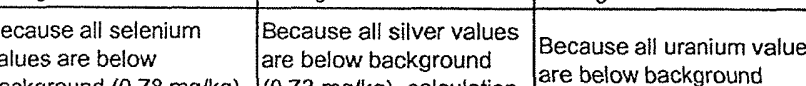
NA

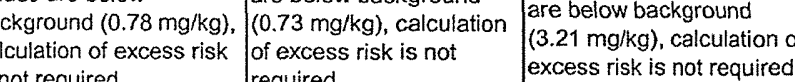


Originator M. J. Appel Miff/f
Project 300 Area Field Remediation

Subject $618-3$ Burial Ground Cleanup Verification $95 \%$ UCL Calculation
Date $\frac{5 / 9 / 06}{14655}$
Job No.
Checked T.M. Blakley ImB

Split-Duplicate Analysis

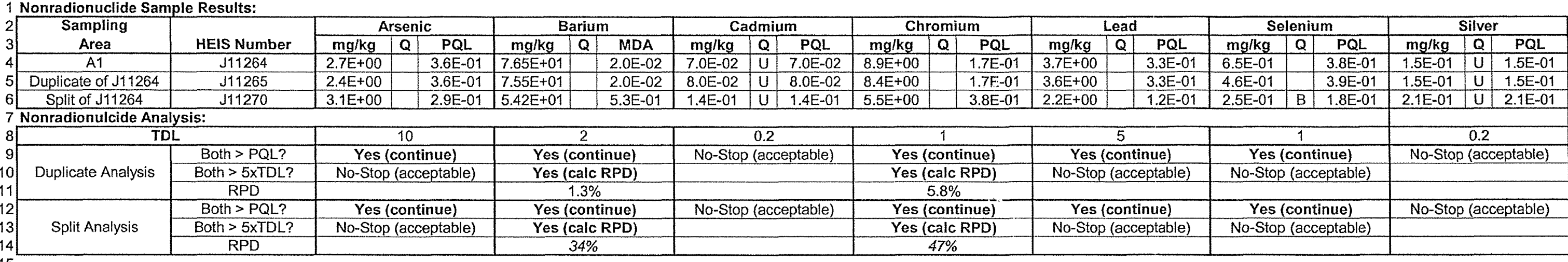

14

16 Radionuclide Sample Results:

\begin{tabular}{|c|c|c|c|c|c|c|c|c|c|c|c|}
\hline \multirow{4}{*}{$\begin{array}{l}176 \\
17 \\
10\end{array}$} & Radionuclide Sample Results: & & Uranium & (Total) & Uraniu & $m-233 / 234$ & Ura & um- & & Urar & nium-238 \\
\hline & Area & HEIS Number & \begin{tabular}{ll|l}
$\mathrm{ma} / \mathrm{ka}$ & 0 & 0
\end{tabular} & & & & ncila & & MDA & & (O) MDA \\
\hline & A1 & J11264 & $1.21 \mathrm{E}+00$ & $1.7 \mathrm{E}-02$ & $4.47 E-01$ & $2.30 \mathrm{E}-01$ & $\frac{2.8 \mathrm{E}-01}{2}$ & $\bar{U}$ & $2.8 \mathrm{E}-01$ & $\frac{.51}{7.45 E-01}$ & $2.3 \mathrm{E}-01$ \\
\hline & Duplicate of $\mathrm{J11264}$ & & $1.34 \mathrm{E}+00$ & & & & & & & & \\
\hline & Solit of J11264 & $\mathrm{J11270}$ & $1.64 \mathrm{E}+00$ & $2.08 \mathrm{E}-02$ & $1.09 \mathrm{E}+00$ & $2.13 \mathrm{E}-02$ & $3.78 \mathrm{E}-02$ & & $3.77 \mathrm{E}-02$ & $1.07 E+00$ & $2.13 \mathrm{E}-02$ \\
\hline \multirow{2}{*}{\multicolumn{12}{|c|}{ Radionuclide Analysis: }} \\
\hline & & & & & \multirow{2}{*}{\multicolumn{2}{|c|}{ Yes (continue) }} & \multirow{3}{*}{\multicolumn{3}{|c|}{ No-Stop (acceptable) }} & & 1 \\
\hline \multirow{4}{*}{$\begin{array}{l}25 \\
26\end{array}$} & \multirow[b]{2}{*}{ Duplicate Analysis } & Both $>\mathbb{N}$ & \multirow{2}{*}{\multicolumn{2}{|c|}{$\begin{array}{c}\text { Yes (continue) } \\
\text { No-Stop (acceptable) }\end{array}$}} & & & & & & \multicolumn{2}{|c|}{ Yes (continue) } \\
\hline & & $\begin{array}{c}\text { Both }>5 \times \text { TDL? } \\
\text { RPD }\end{array}$ & & & No-Stop & (acceptable) & & & & No-Stop & (acceptablei) \\
\hline & \multirow{2}{*}{ Split Analysis } & Both > MDA? & \multirow{2}{*}{\multicolumn{2}{|c|}{$\begin{array}{c}\text { Yes (continue) } \\
\text { No-Stop (acceptable) }\end{array}$}} & \multirow{2}{*}{\multicolumn{2}{|c|}{$\begin{array}{c}\text { Yes (continue) } \\
\text { No-Stop (acceptable) }\end{array}$}} & \multirow{2}{*}{\multicolumn{3}{|c|}{ No-Stop (acceptable) }} & \multirow{2}{*}{\multicolumn{2}{|c|}{$\begin{array}{c}\text { Yes (continue) } \\
\text { No-Stop (acceptabie) }\end{array}$}} \\
\hline & & Both $>5 \times$ TDL? & & & & & & & & & \\
\hline
\end{tabular}

30 Note: The significance of the reported RPD values, including values greater than $30 \%$, is addressed within the Data Quality Assessment for the Cleanup Verification Package for this site.

$31 \mathrm{~B}=$ analyte found in method blank

$\mathrm{RPD}=$ relative percent difference
$\mathrm{TDL}=$ target detection limit

$34 \mathrm{POL}=$ rectical

$35 \mathrm{Q}=$ qualifier 
CVP-2006-00005

Rev. 0

\section{CALCULATION COVER SHEET}

Project Title:

Area

Discipline

Subject

Computer Program
618-3 Burial Ground Sample Design 300 Area

Environmental Engineering

618-3 Shallow Zone Sampling Plan

Excel
Job No.

14655

Calc. No. 0300X-CA-V0066

Program No. $\quad$ Excel 2003

The attached calculations have been generated to document compliance with established cleanup levels. These documents should be used in conjuction with other relevent documents in the administrative record.

Committed Calculation $\quad$ Preliminary $\square \quad$ Superseded $\square \quad$ Voided

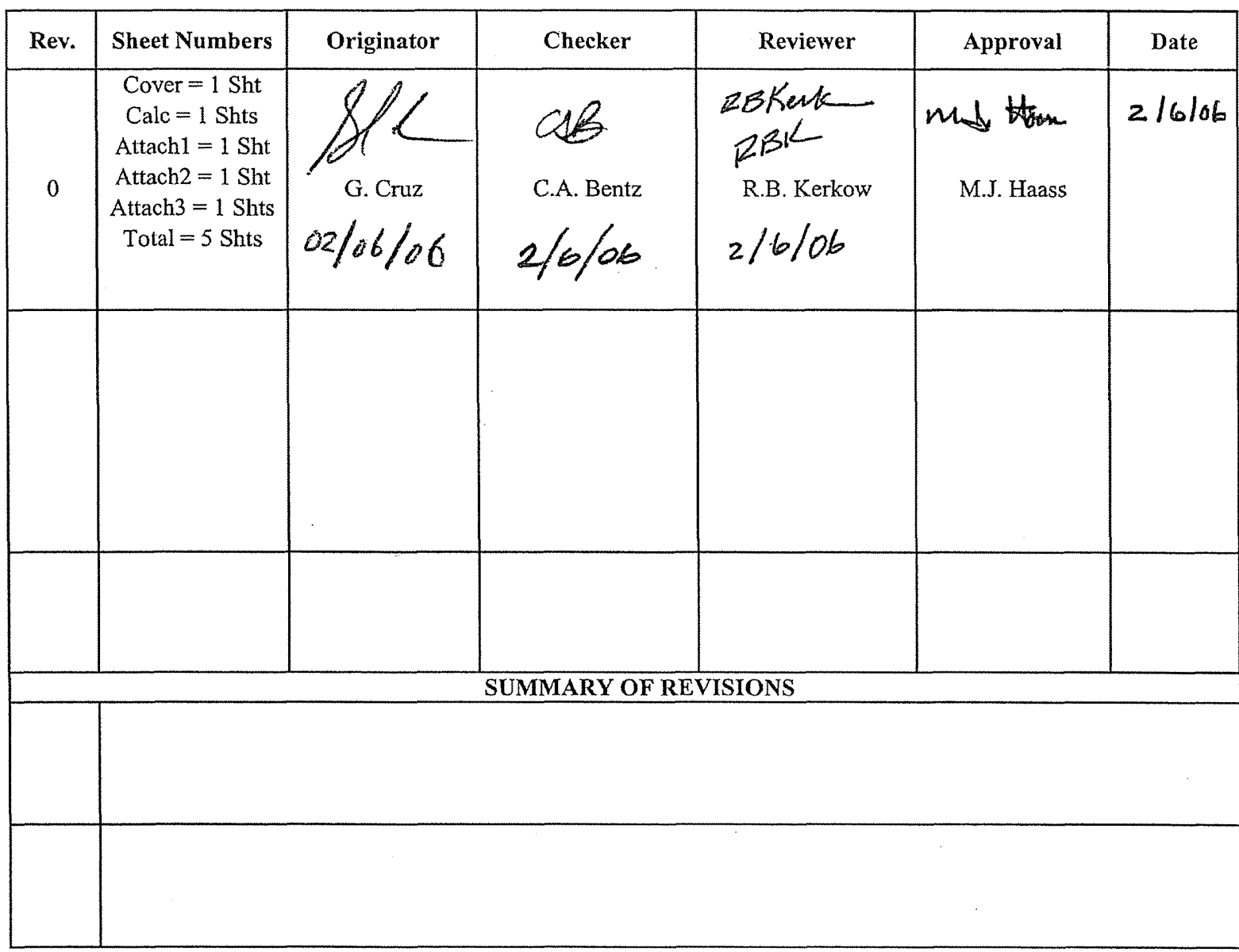

* Obtain calc no. from DIS

DE01437.03 (12/09/2004) 
CVP-2006-00005

Rev. 0

Washington Closure Hanford

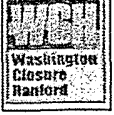

Originator G. Cruz

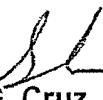

Project

618-3 Burial Ground Sample Design

Subject 618-3 Shallow Zone Sampling Plan

\section{CALCULATION SHEET}

Calc. No. 0300X-CA-V0066 Rev. No. 0

Job No. 14655 Checked CSB Date 2/6/06 Sheet No. 1 of 1

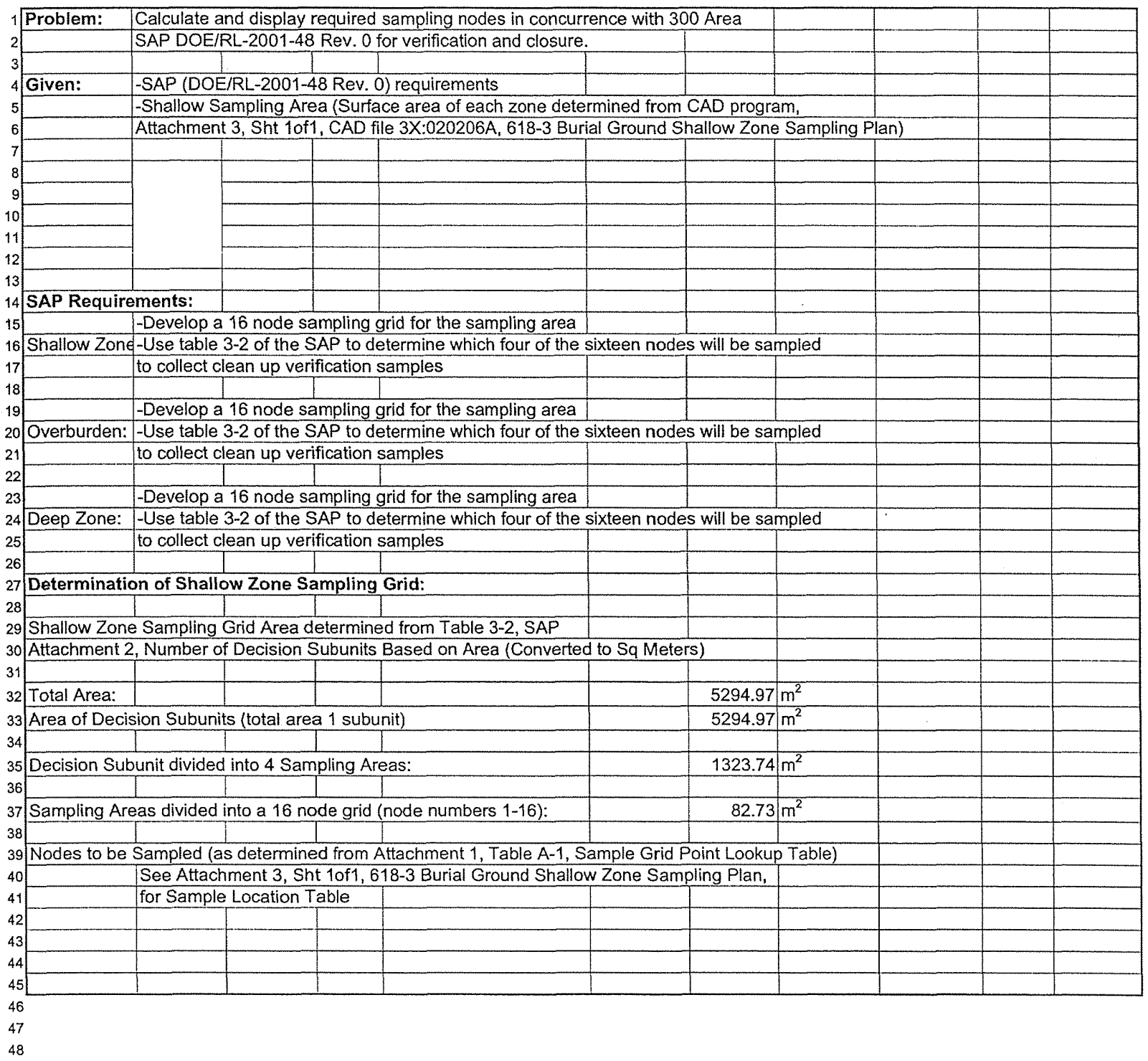


CVP-2006-00005

Rev. 0

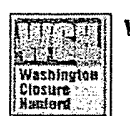

Originator

Project

Subject

Washington Closure Hanford

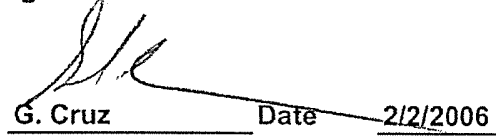

618-3 Burial Ground Sample Design 618-3 Shallow Zone Sampling Plan
Calc. No.0300X-CA-V0066 Rev. No. 0

Job No. $14655 \quad$ Checked

CB Date $2 / 5 / 06$

\section{ATTACHMENT 1}

2

${ }_{3}$ Sample Grid Point Lookup Table.

4

\begin{tabular}{|c|c|c|c|c|c|c|c|c|c|c|}
\hline Default Plan & $\begin{array}{l}\text { Sampling } \\
\text { Area } 1\end{array}$ & $\begin{array}{c}\text { Sampling } \\
\text { Area } 2\end{array}$ & $\begin{array}{c}\text { Sampling } \\
\text { Area } 3\end{array}$ & $\begin{array}{c}\text { Sampling } \\
\text { Area } 4\end{array}$ & $\begin{array}{c}\text { Sampling } \\
\text { Area } 5\end{array}$ & $\begin{array}{c}\text { Sampling } \\
\text { Area } 6\end{array}$ & $\begin{array}{c}\text { Sampling } \\
\text { Area } 7\end{array}$ & $\begin{array}{c}\text { Sampling } \\
\text { Area } 8\end{array}$ & $\begin{array}{c}\text { Sampling } \\
\text { Area } 9\end{array}$ & $\begin{array}{c}\text { Sampling } \\
\text { Area } 10\end{array}$ \\
\hline Closeout & 3 & 6 & 1 & 4 & 5 & 1 & 3 & 3 & 4 & 16 \\
\hline Closeout & 4 & 7 & 11 & 3 & 15 & 15 & 5 & 13 & 10 & 10 \\
\hline Closeout & 16 & 3 & 2 & 7 & 7 & 10 & 11 & 4 & 3 & 14 \\
\hline Closeout & 10 & 15 & 4 & 12 & 1 & 13 & 4 & 8 & 16 & 4 \\
\hline Not Sampling & 2 & 14 & 5 & 9 & 13 & 12 & 8 & 2 & 14 & 8 \\
\hline Not Sampling & 13 & 10 & 9 & 13 & 2 & 16 & 1 & 12 & 5 & 3 \\
\hline Not Sampling & 6 & 1 & 10 & 8 & 14 & 4 & 16 & 5 & 8 & 6 \\
\hline Not Sampling & 1 & 9 & 13 & 1 & 10 & 5 & 12 & 1 & 1 & 15 \\
\hline Not Sampling & 9 & 12 & 7 & 5 & 6 & 2 & 6 & 7 & 15 & 9 \\
\hline Not Sampling & 15 & 16 & 15 & 14 & 16 & 6 & 2 & 15 & 11 & 1 \\
\hline Not Sampling & 8 & 13 & 8 & 10 & 12 & 11 & 13 & 14 & 2 & 12 \\
\hline Not Sampling & 5 & 2 & 3 & 11 & 4 & 3 & 9 & 10 & 7 & 11 \\
\hline Not Sampling & 7 & 11 & 14 & 15 & 11 & 14 & 14 & 6 & 13 & 2 \\
\hline Not Sampling & 11 & 4 & 6 & 2 & 9 & 7 & 7 & 11 & 9 & 7 \\
\hline Not Sampling & 12 & 8 & 16 & 16 & 3 & 8 & 15 & 9 & 6 & 13 \\
\hline Not Sampling & 14 & 5 & 12 & 6 & 8 & 9 & 10 & 16 & 12 & 5 \\
\hline
\end{tabular}


CVP-2006-00005

Rev. 0

Washington Closure Hanford

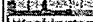

Wasting

Gation:

Originator G. Cruz

Project

618-3 Burial Ground Sample Design

Subject 618-3 Shallow Zone Sampling PIan
Calc. No. 0300 X-CA-V0066 Rev. No. 0

Job No. 14655 Checked

Sheet No. 1 of 1

\section{ATTACHMENT 2}

${ }_{3}$ Number of Decision Subunits Based on Area.

4

\begin{tabular}{|c|c|c|c|c|c|}
\hline \multicolumn{6}{|c|}{ Site Verification Sampling Frequencies Based on Area. } \\
\hline Decision Unit ${ }^{*}$ & Waste Site Size ${ }^{b}$ & $\begin{array}{l}\text { Decision } \\
\text { Suhunits }\end{array}$ & Blocks & $\begin{array}{l}\text { Discrete } \\
\text { Samples }\end{array}$ & $\begin{array}{c}\text { Composite } \\
\text { Samples }\end{array}$ \\
\hline \multirow{3}{*}{$\begin{array}{l}\text { Shallow zone - } \\
01015 \mathrm{ft}\end{array}$} & Small: $<100,000 \mathrm{ft}^{2}$ & 1 & 4 & 16 & 4 \\
\hline & Medium: $>100,000 \mathrm{ft}^{2}<400,000 \mathrm{ft}^{2}$ & 4 & 16 & 64 & 16 \\
\hline & Large: $>400,000 \mathrm{ft}^{2}$ & 8 & 32 & 128 & 32 \\
\hline \multirow{3}{*}{$\begin{array}{l}\text { Deep Zone - } \\
>15 \mathrm{ft}\end{array}$} & Small: $<100.000 \mathrm{ft}^{2}$ & 1 & 4 & 16 & 4 \\
\hline & Medium: $>100,000 \mathrm{ft}^{2}<400,000 \mathrm{ft}^{2}$ & 4 & 16 & 64 & 16 \\
\hline & Large: $>400.000 \mathrm{ft}^{2}$ & 8 & 32 & 128 & 32 \\
\hline \multirow{3}{*}{$\begin{array}{l}\text { Overburen/layback } \\
\text { stockpiles }\end{array}$} & Small: $<100.000 \mathrm{ft}^{2}$ & 1 & 4 & 16 & 4 \\
\hline & Medium: $>100,000 \mathrm{ft}^{2}<400,000 \mathrm{ft}^{2}$ & 4 & 16 & 64 & 16 \\
\hline & Large: $>400,000 \mathrm{ft}^{2}$ & 8 & 32 & 128 & 32 \\
\hline \multirow{3}{*}{$\begin{array}{l}\text { Staging pile areas } \\
\text { (residual soil) }\end{array}$} & Small: $<100,000 \mathrm{ft}^{2}$ & 1 & 4 & 16 & 4 \\
\hline & Medium: $>100,000 \mathrm{ft}^{2}<400,000 \mathrm{ft}^{2}$ & 4 & 16 & 64 & 16 \\
\hline & Large: $>400.000 \mathrm{ft}^{2}$ & 8 & 32 & 128 & 32 \\
\hline
\end{tabular}

" The shallow zone, deep zone, overburden stockpilc, and staging pile areas cach represent single decision units. The total number of decision

units will vary because individual waste sitcs may not have a decp zonc, overburden stockpile, and/or staging pile areas.

Arca of exposed surface after excavation or area of stockpile base (as applicable)

" Decision subunits are divided into four blocks to ensure that random sampling locations are not bunched together in one arca 


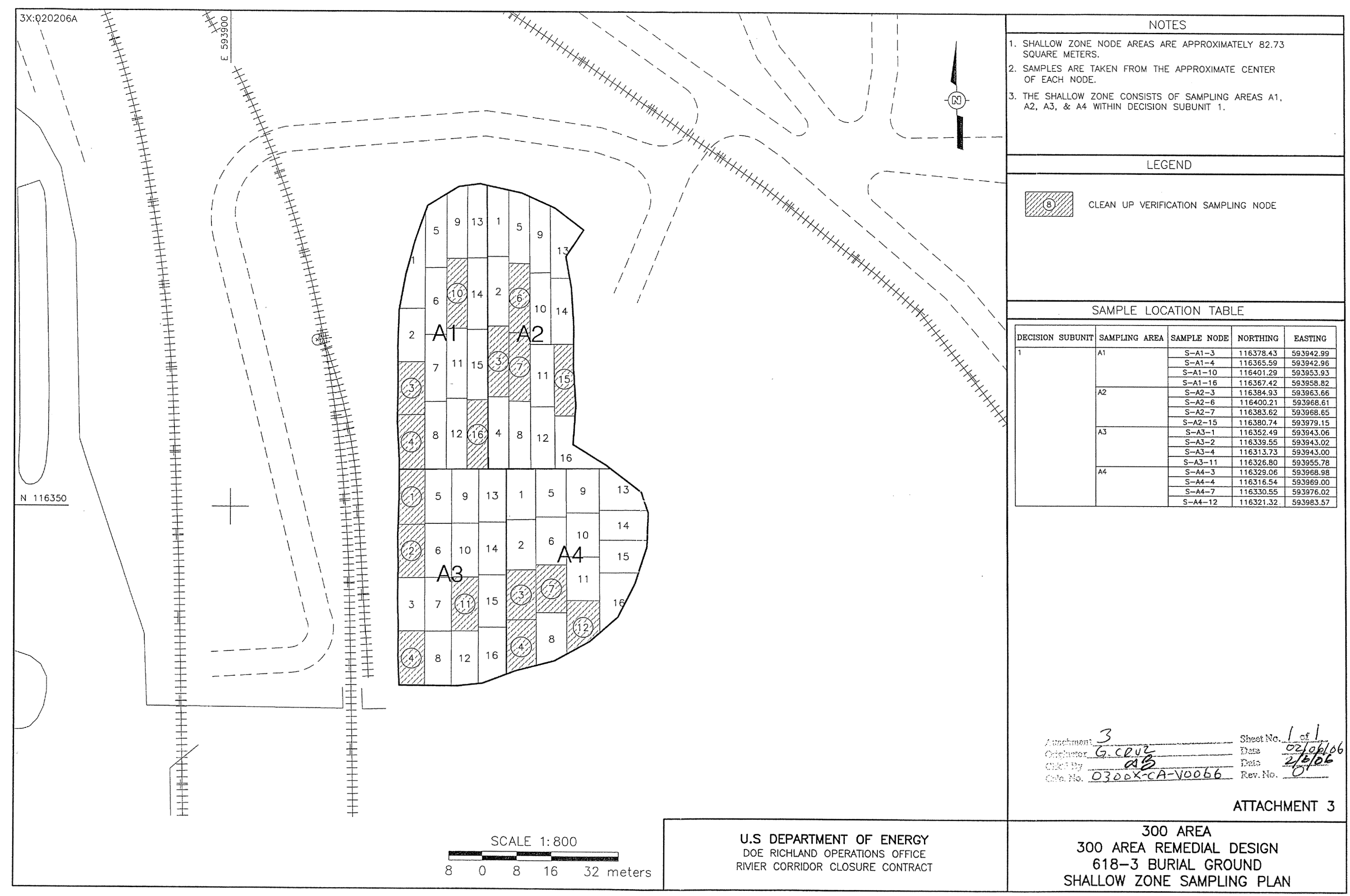




\section{DISTRIBUTION}

U.S. Department of Energy

Richland Operations Office

S. L. Sedgwick

D. C. Smith (5)

RL Correspondence Control

DOE-RL Public Reading Room
A3-04

A3-04

A5-10

$\mathrm{H} 2-53$

A0-21

$\mathrm{H} 9-02$

$\mathrm{H} 9-01$

$\mathrm{X} 4-08$

$\mathrm{H} 9-01$

L6-06

L6-06

$\mathrm{HO}-23$

$\mathrm{H} 9-02$

L6-06

L6-06

$\mathrm{HO}-23$

J. E. Thomson

Records and Document Control

$\mathrm{H} 0-30$

P8-55 
CVP-2006-00005

Rev. 0

Distr-2 